\title{
Analysis of Engineering Geology Indices in Three Units of Atamir Formation in Kope Dagh Zone
}

\author{
Bizhan Shirdel \\ Department of Geology, Karaj Branch, Islamic Azad University, Karaj, Iran \\ Email: bizhan.shirdel@gmail.com
}

Received 20 October 2015; accepted 26 December 2015; published 29 December 2015

Copyright (C) 2015 by author and Scientific Research Publishing Inc.

This work is licensed under the Creative Commons Attribution International License (CC BY). http://creativecommons.org/licenses/by/4.0/

(c) (i) Open Access

\section{Abstract}

This is a field report on a comprehensive study of the Atamir Formation from the engineering geology perspective using the related indices. The Atamir Formation of the Cretaceous Period, which has outcropped in the form of thick frequencies of grey-knotted sandstone and black shales, is situated in the Kope Dagh zone. A survey of discontinuities together with bedding was carried out to study slope stability. The layers have a general east-west trend with a gentle slope towards the south. Because of the tectonic and stratigraphic differences, and with the purpose of facilitating surveys related to joint study of the outcrop, the formation in the study region was divided into three units. The lower unit is made of shale, the middle of sandstone, and the upper of marlstone. All three units were studied from the perspective of geomechanical classification, rock mass indices, geological strength, geomechanical indices, and wedge instability analysis under dry and wet conditions, and the results were investigated in the form of various images and figures. The Dips software was used to display the rose diagram and stereographic projection of each unit, the Swedge software to analyze instability of the wedges, and the Roctab software to analyze the geomechanical parameters and present the outputs along with the description of each unit.

\section{Keywords}

Atamir Formation, Kope Dagh Zone, Engineering Geology Indices, Joint Study, Software Analysis, Wedge Stability Analysis

\section{Introduction}

Based on field surveys and geological surveys such as outcrop studies, the Atamir Formation was divided into 
three separate units to study the characteristics of the discontinuities and of the rock mass in each one. This study intended to review results of research carried out on the Atamir Formation in detail and present a field report. Therefore, the units were studied and the results were compared.

\section{Results}

\subsection{The Atamir Formation Unit One $K$ (at) 1}

This lithology included black shales. In the study region, there were three dominant discontinuity sets (two joint sets together with bedding) and random discontinuities. Table 1 lists the characteristics of these discontinuities. Table 2 lists geotechnical characteristics of the various discontinuities in the rock masses. Figures 1-3 show the Stereographic characteristics of Figures 4-7 show statistical analysis.

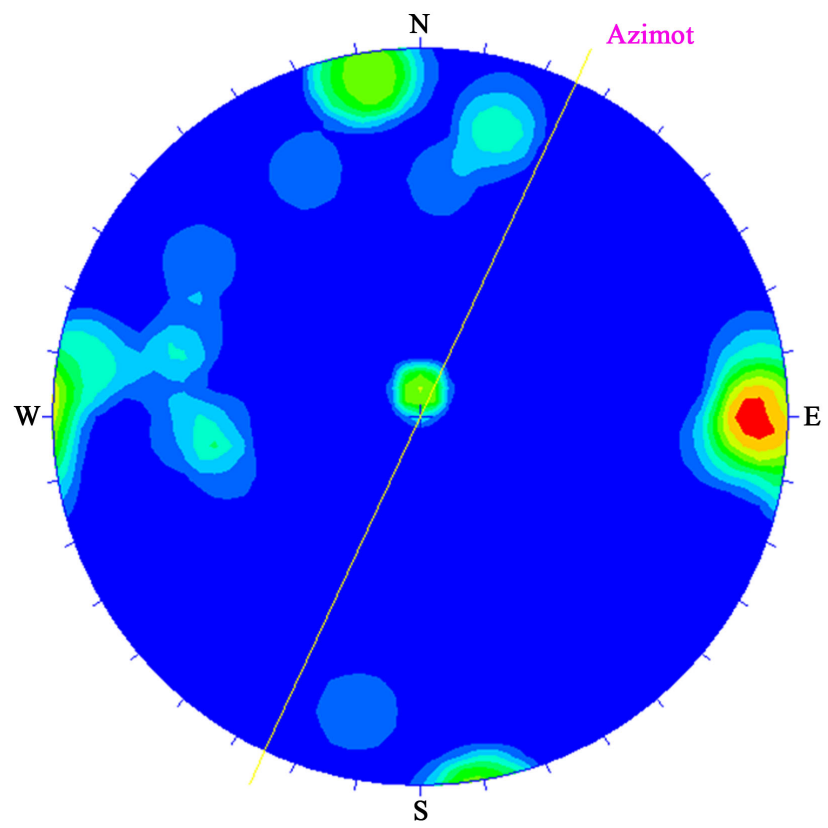

Fisher

Concentrations

$\%$ of total per $1.0 \%$ area

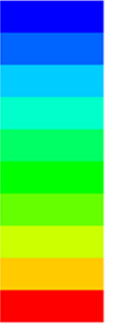

$0.00 \%-2.00 \%$

$2.00 \%-4.00 \%$

$4.00 \%-6.00 \%$

$6.00 \%-8.00 \%$

$8.00 \%-10.00 \%$

$10.00 \%-12.00 \%$

$12.00 \%-14.00 \%$

$14.00 \%-16.00 \%$

$16.00 \%-18.00 \%$

$18.00 \%-20.00 \%$

No Bias Correction

Max. Conc. $=19.4658 \%$

Equal Angle
Lower Hemisphere
28 Poles
28 Entries

Figure 1. Stereographic image of the discontinuities in unit one of the Atamir Formation K (at) 1.

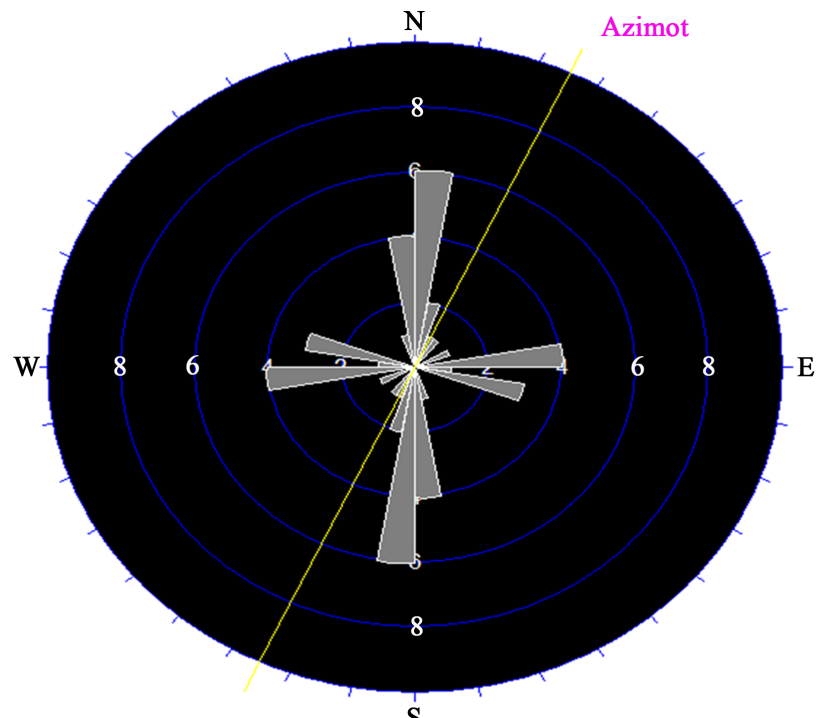

Apparent Strike

10 max planes/arc

at outer circle

Trend/Plunge of

Face Normal $=0.90$

(direct away from viewer)

No Bias Correction

24 Planes Plotted

Within 45 and 90

Degrees of Viewing

Face

Figure 2. Rose diagram of the discontinuities in unit one of the Atamir Formation K (at) 1. 



Figure 3. Stereography of discontinuities in unit one of the Atamir Formation K (at) 1.

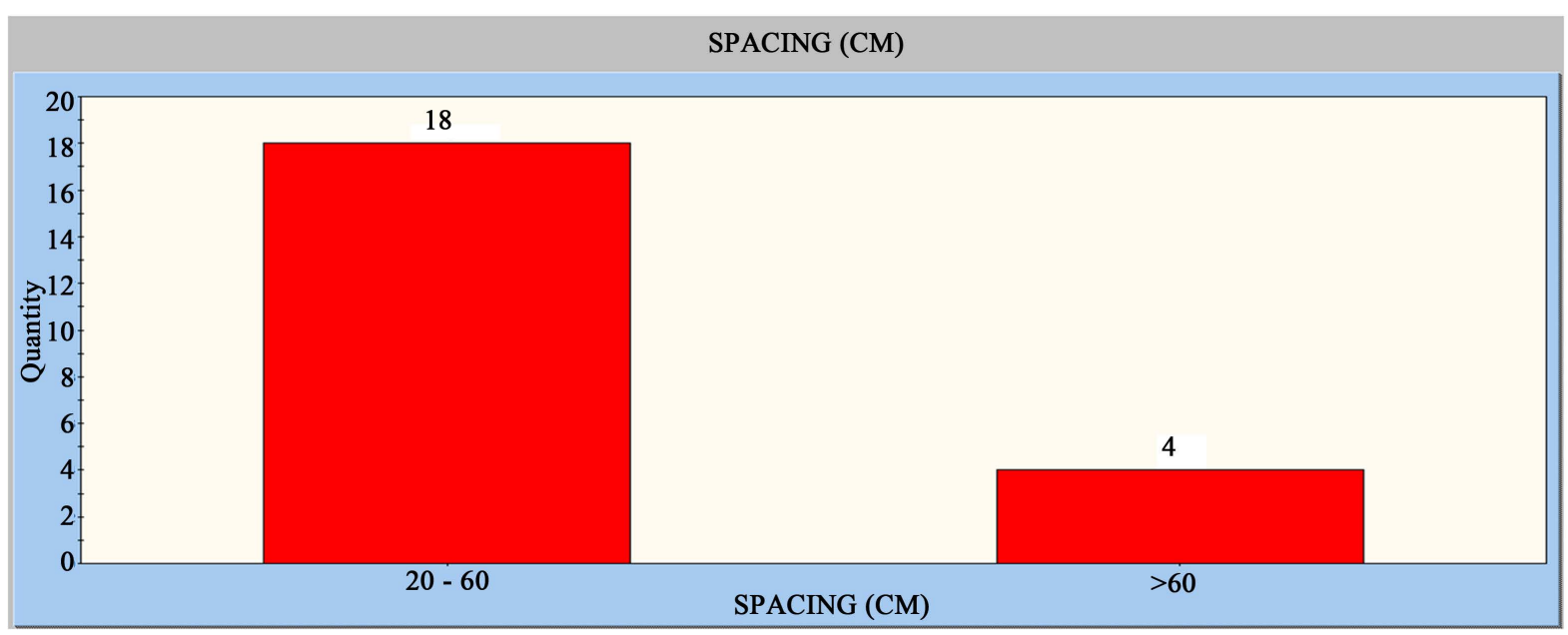

Figure 4. Statistical analysis of discontinuity spacings in unit one of the Atamir Formation K (at) 1.



Figure 5. Statistical analysis of discontinuity fillings in unit one of the Atamir Formation K (at) 1. 


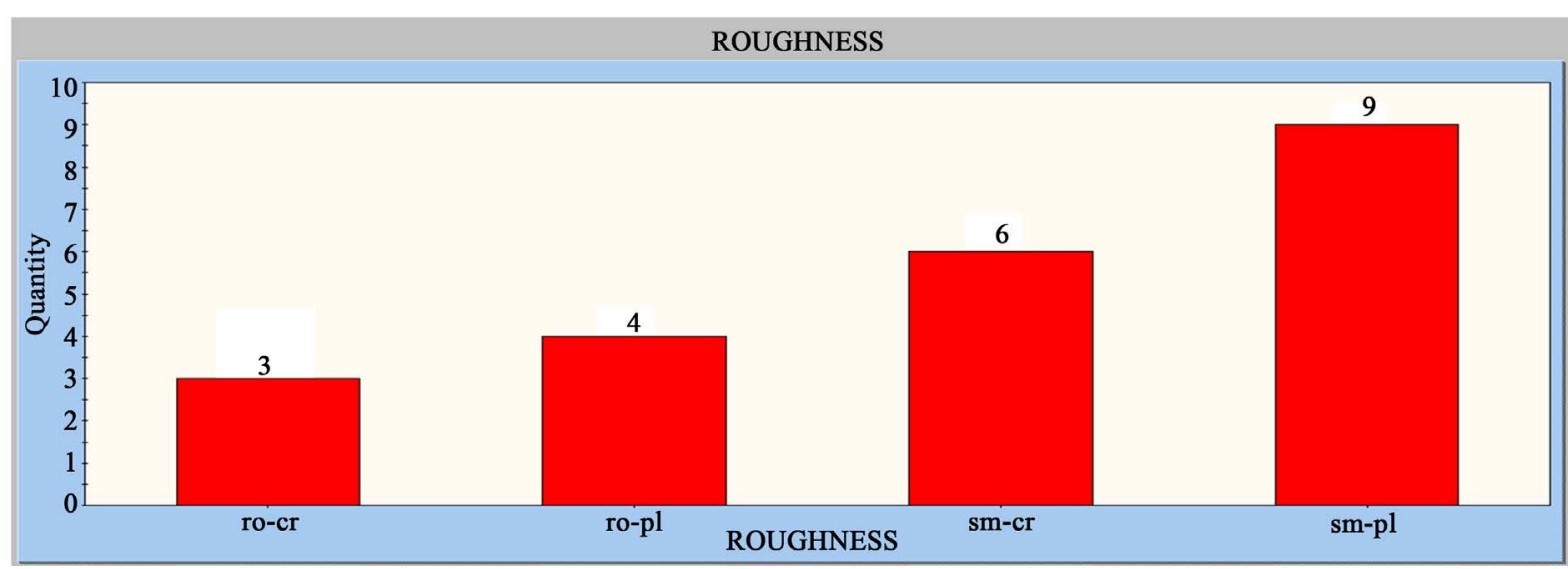

Figure 6. Statistical analysis of discontinuity roughness in unit one of the Atamir Formation K (at) 1.

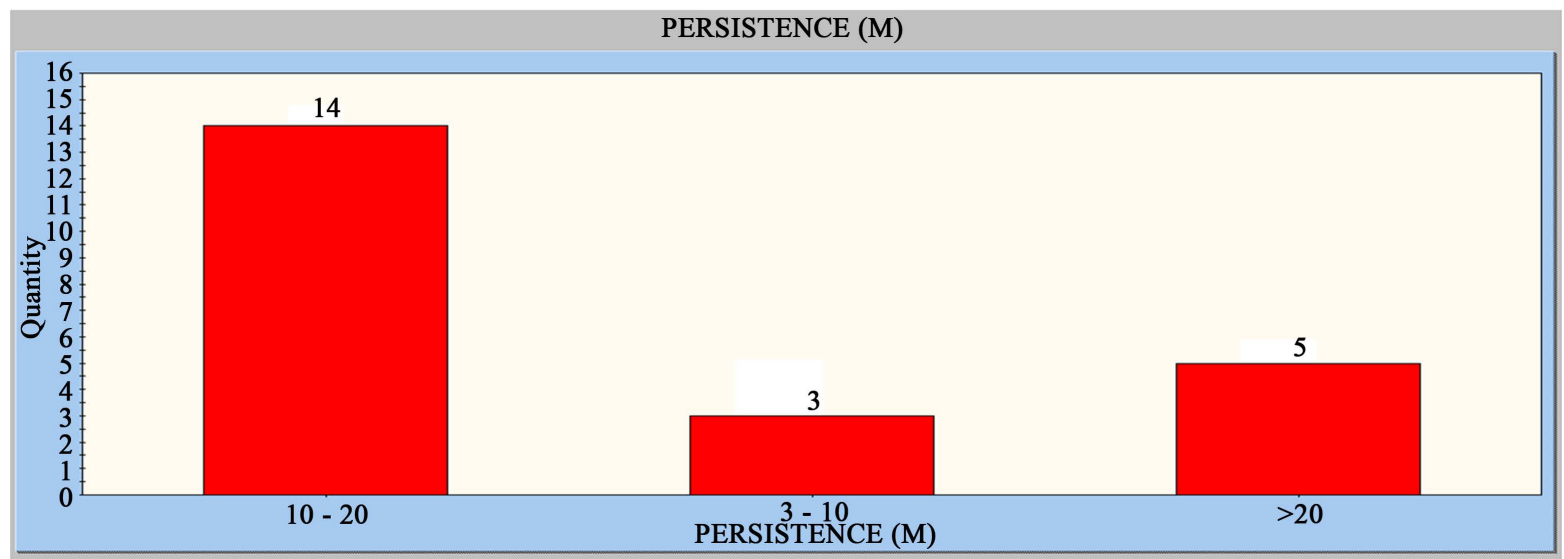

Figure 7. Statistical analysis of discontinuity orientation in unit one of the Atamir Formation K (at) 1.

Table 1. Characteristics of the discontinuities in unit one of the Atamir Formation K (at) 1.

\begin{tabular}{cccc}
\hline Discontinuity & ID & Dip & Dip Direction \\
\hline Js1 & 1 & 83 & 270 \\
Js2 & 2 & 85 & 170 \\
Bedding & 3 & 8 & 180 \\
\hline
\end{tabular}

Table 2. Geotechnical characteristics of the various discontinuities in the rock masses of unit one in the Atamir Formation K (at) 1.

\begin{tabular}{|c|c|c|c|c|c|c|c|c|c|c|c|c|c|c|c|c|c|}
\hline \multirow[b]{2}{*}{ Joint Sets } & \multirow{2}{*}{\multicolumn{2}{|c|}{$\begin{array}{c}\text { Dip } \\
\text { Direction }\end{array}$}} & \multirow{2}{*}{$\begin{array}{c}\text { Joint } \\
\text { Frequency }\end{array}$} & \multicolumn{7}{|c|}{ Persistence (m) } & \multicolumn{7}{|c|}{ Joint Roughness (\%) } \\
\hline & & & & \multicolumn{2}{|c|}{$y>20 \%$} & $0 \%-20 \%$ & $3 \%-10 \%$ & \multicolumn{2}{|c|}{$1 \%-3 \%$} & $<1 \%$ & $\begin{array}{c}\text { Very } \\
\text { Rough }\end{array}$ & $\begin{array}{c}\text { Rough } \\
\text { - }\end{array}$ & \multicolumn{2}{|c|}{ Rough-Smooth } & Smooth & \multicolumn{2}{|c|}{ h Slickenside } \\
\hline Js2 & $170 \backslash 8$ & & 30 & - & & 70 & 30 & & & - & - & 30 & & 70 & - & & - \\
\hline Bedding & $180 \backslash$ & & 20 & 100 & & - & - & & & - & - & - & & 100 & - & & - \\
\hline $\begin{array}{c}\text { Joint } \\
\text { Alteration }\end{array}$ & $\begin{array}{c}\text { Joint } \\
\text { Water }\end{array}$ & $\begin{array}{c}>5 \\
\mathrm{~mm} \\
\%\end{array}$ & $\begin{array}{c}1-5 \\
\mathrm{~mm}\end{array}$ & $\begin{array}{c}0.1-1 \\
\mathrm{~mm} \\
\%\end{array}$ & $\begin{array}{c}<0.1 \\
\mathrm{~mm} \\
\%\end{array}$ & Close & $\begin{array}{c}\text { Soft } \\
\text { filling } \\
\underset{\%}{\operatorname{mm} 5<} \\
\%\end{array}$ & $\begin{array}{l}\text { Soft } \\
\text { filling } \\
\text { am } 5> \\
\%\end{array}$ & $\begin{array}{r}\mathrm{H} \\
\text { fill } \\
\mathrm{mm}\end{array}$ & $\begin{array}{l}\text { ard } \\
\text { ing } \\
5> \\
0\end{array}$ & $\begin{array}{c}\text { Hard } \\
\text { filling } \\
\text { mm } 5< \\
\%\end{array}$ & $\begin{array}{c}\text { Clean } \\
\%\end{array}$ & $\begin{array}{c}<60 \\
\mathrm{~mm} \\
\%\end{array}$ & $\begin{array}{c}60-20020 \\
\text { mm } \\
\%\end{array}$ & $\begin{array}{c}00-600 \\
\mathrm{Mm} \\
\%\end{array}$ & $\begin{array}{c}0.6-2 \mathrm{~m} \\
\%\end{array}$ & $\begin{array}{c}n>2 \mathrm{~m} \\
\%\end{array}$ \\
\hline \multirow{2}{*}{ W2 } & \multirow{2}{*}{ Dry } & - & 100 & - & - & - & - & 100 & & . & - & - & - & - & 100 & - & - \\
\hline & & 40 & 60 & - & - & - & - & - & & 0 & - & 60 & - & - & 50 & 50 & - \\
\hline
\end{tabular}


Rock masses were classified based on the methods proposed by Bieniawski (RMR), Barton (Q), and Hoek (GSI), all of which are discussed below.

\subsubsection{Geomechanical Classification (RMR)}

\section{1) Compressive strength of intact rock}

The value of this parameter was determined based on the strength characteristic of outcropped masses and on performing tests.

2) Rock quality designation

The rating of 8 may be given depending on the state of the discontinuity system.

3) Joint spacing

The rating for this parameter was the least value of spacing. In the study region, there were three sets of discontinuities (two sets of dominant discontinuities together with bedding), and the minimum discontinuity spacing was less than 10 centimeters. Considering the geomechanical classification parameters, the rating of 8 - 10 was given to this parameter.

4) Condition of discontinuities

The joints in the rock masses in unit one of the Atamir Formation, $\mathrm{K}$ (at) 1, were 10 - 20 meters long, clay, calcite, and few traces of iron oxide were the main filling, the joints were smooth to a little rough and, with respect to euhidrality, the rock masses were planar and moderately weathered. Considering the existing parameters, the rating given to this parameter was 10 .

5) Groundwater

Presence of groundwater in a region is undoubtedly very important, especially if permeability is high. Considering the conditions of the rock masses in the region, the seepage state was determined and given the rating of 4.

6) Discontinuity orientations

This parameter is determined by the mode of transgression of the structure towards the jointed rock mass, by the dips of the layers (and of the discontinuities), and by the orientation of the structure (which has been used by Feenstra \& Wickham in 1975 [1] and suggested by Bieniawski 1973) [2].

The presented parameters 2 - 1 to 2 - 5 are used for determining the value of RMR that, for the rock masses in unit one of the Atamir Formation, K (at) 1, was 34 - 36. Based on this, these rock masses were placed in the poor class; pertaining data are shown in Table 3.

\subsubsection{Qualitative Index of the Rock Mass (Q)}

The index $\mathrm{Q}$ for the rock masses in unit one of the Atamir Formation, K9 (at) 1, was estimated based on the following 6 parameters.

1) Rock quality designation (RQD)

Considering the condition of the rock masses, the value of 43 - 48 was given to the RQD parameter of unit one in the Atamir Formation, K (at) 1.

Table 3. Geomechanical classification of the rock masses in unit one of the Atamir Formation K (at) 1.

$\begin{array}{ccc}\text { Parameter } & \text { Value } & \text { Rating } \\ \text { UCS (Mpa) } & 25-50 & 4 \\ \text { RQD } & 25-50 & 8-10 \\ \text { Spacing (mm) } & 60-200 & 10 \\ \text { Condition of discontinuities } & \text { Flow } & 34-35 \\ \text { Groundwater } & \text { Poor rock } \\ \text { RMR } & 115 \\ \text { Class no. } & 15-25 \\ \text { Cohesion of the rock mass (KPa) } & \\ \text { Friction angle of the rock mass (deg) } & \end{array}$


2) Number of joint sets $\left(\mathrm{J}_{\mathrm{n}}\right)$

Based on the data obtained from the geological field surveys, this parameter received the value of 12 for unit one of the Atamir Formation, K (at) 1.

3) Discontinuity surface roughness $\left(\mathrm{J}_{\mathrm{r}}\right)$

This parameter shows the degree of roughness of the discontinuities and, based on Barton's theory, the weakest set of critical discontinuities or discontinuities filled with clay materials in the related zone must be determined. Considering the conditions, the value of one was given to this parameter for unit one of the Atamir Formation, $\mathrm{K}$ (at) 1.

4) Joint alteration number $\left(\mathrm{J}_{\mathrm{a}}\right)$

Considering the joint filling and the apparent conditions of discontinuity surfaces, this parameter received the value of 4 for unit one of the Atamir Formation, K (at) 1.

5) Joint water reduction factor $\left(\mathrm{J}_{\mathrm{w}}\right)$

This parameter measures water pressure, which inversely affects shear strength of the discontinuity. Based on data collected in the study region, the value of 0.66 was considered for this parameter.

6) Stress reduction factor (SRF)

This parameter is determined based on the characteristics of the study region including the existing stresses, the tectonic conditions, the shear zones, etc. Since the necessary tests were not performed, the estimated value of one was used for this factor.

Considering the ratings of the six parameters, and using the presented relationship, the expected value determined for the Q index was 0.592 - 0.66 for the rock masses in unit one of the Atamir Formation, K (at) 1, which places them in the class of very poor rocks. Data are shown in Table 4.

\subsubsection{Geological Strength Index (GSI) of the Rock Masses}

Using the following three methods, the value of the geological strength index for the rock masses in unit one was determined.

\section{1) Geological strength index of the rock mass (GSI) (Figure 8)}

The GSI system is the only classification system that is directly related to engineering parameters such as Mohr-Coulomb and Hoek-Brown parameters. Conventional methods for determining strength parameters and rock mass modulus in Iran and other countries include plate-loading tests and block shear in situ. However, these tests can be performed only if exploration drilling has been carried out and, in addition to that, they are very costly. Therefore, many studies have been conducted and numerous attempts made for developing and introducing methods to indirectly determine engineering parameters of rock masses, one of which is the GIS system [3]. In the following sections, the GSI of rock masses in unit one will be discussed.

\section{2) Determining GSI based on field observations}

Based on field studies and observations, the value of geological strength index of rock masses in unit one of the Atamir Formation, K (at) 1 was 35 - 45.

\section{Table 4. The Q index of the rock masses in unit one of the Atamir Formation, K (at) 1.}

\begin{tabular}{ccc}
\hline Parameter & Description & Value \\
\hline RQD & $43-48$ & $43-48$ \\
$\mathrm{~J}_{\mathrm{n}}$ & Three joint sets with random & 12 \\
$\mathrm{~J}_{\mathrm{r}}$ & Smooth or rough to $\underline{\text { Craw } \text { or Planar }}$ & 1 \\
$\mathrm{~J}_{\mathrm{a}}$ & Softening or low friction clay mineral coatings & 4 \\
$\mathrm{~J}_{\mathrm{w}}$ & Inflow & 0.66 \\
$\mathrm{SRF}$ & Medium stress, favorable stress condition & 1 \\
$\mathrm{Q}$ & $0.592-0.66$ & Very poor rock
\end{tabular}




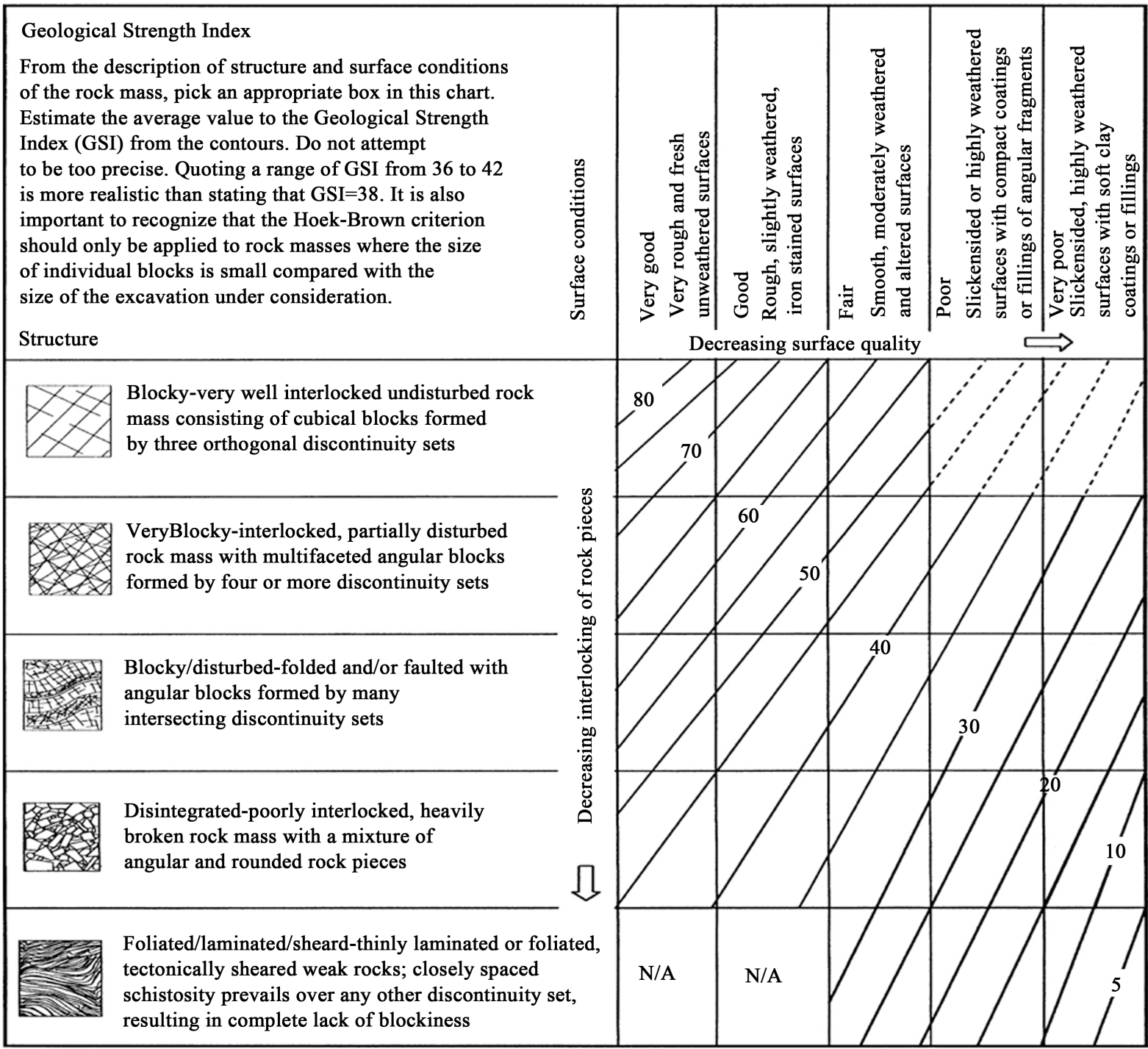

Figure 8. The GSI range of the rock masses in unit one of the Atamir Formation K (at) 1 in the GSI classification diagram.

\subsubsection{Determination of Geomechanical Parameters of the Rock Masses in Unit One of the Atamir Formation K (at) 1}

To determine these parameters, the GSI was considered 35 - 45. Since cohesive strength and angle of internal friction are among the input parameters in most methods of analysis, the Mohr-Coulomb and Hoek-Brown criteria had to be fitted to determine these two parameters. Results are listed in Table 5 and shown in Figures 9-11.

\subsubsection{Analysis of Wedge Instability in Unit One of the Atamir Formation, $K$ (at) 1 , under Dry and Wet Conditions}

Analysis of wedge instability was performed using SWEDGE. This software, which was developed by the ROCSCIENCE Company, analyzes wedge stability in rock slopes, degree of cohesion, geomechanical characteristics, etc., studies stability from various aspects, analyzes areas with rock fall potential using the StereoNet network, follows discontinuities and determines and analyzes intersection points of wedges, and plots the StereoNet using input data. Figure 12 shows stereographic images of the joint sets. Applying the primary parameters, the characteristics of the largest wedges that can be formed in the walls are determined. According to the performed analysis, wedge slide will happen along the interface between two discontinuities, and the factor of safety (FS) will be 0.07743 . Figures $13-18$ show other views. 


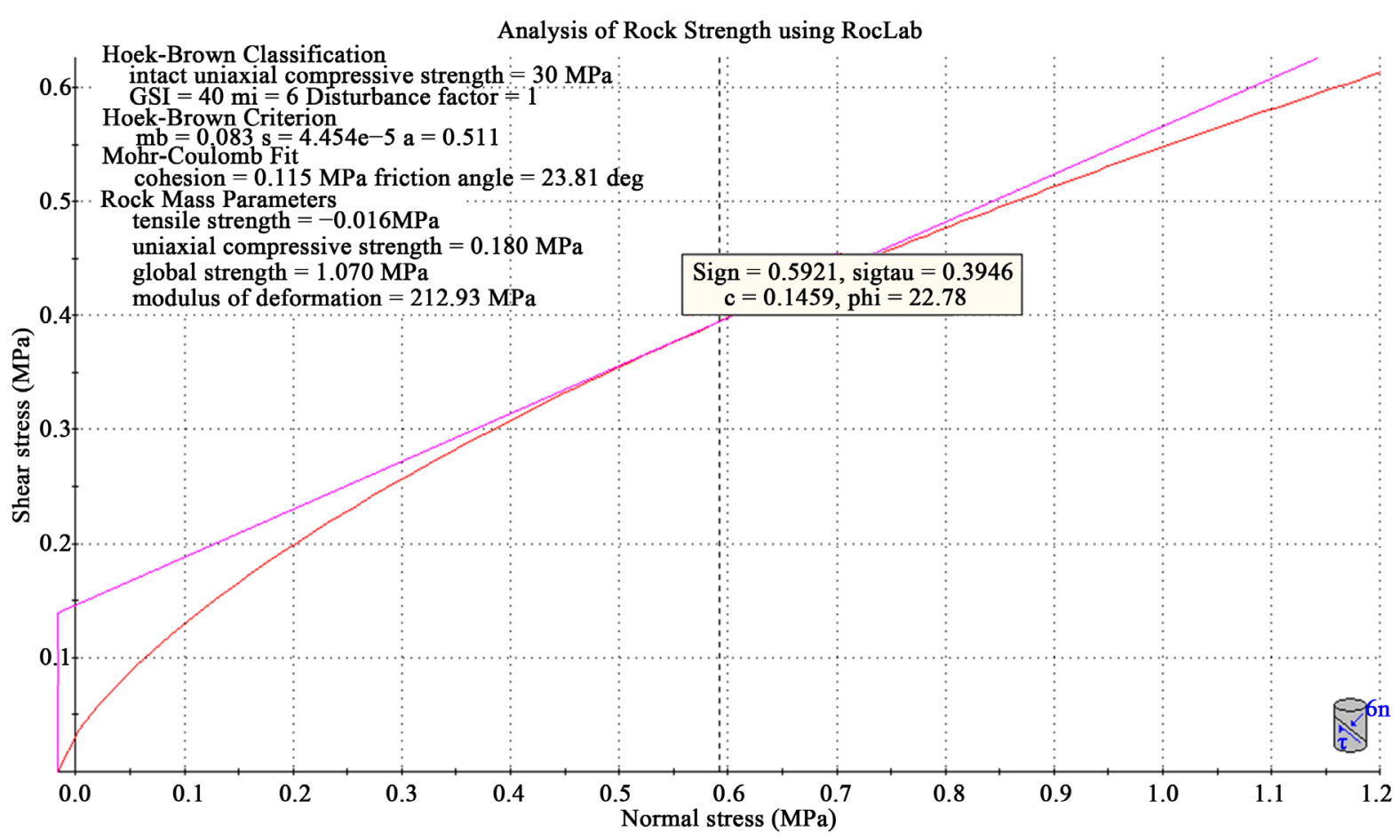

Figure 9. Fitting the data on the rock masses in unit one of the Atamir Formation, K (at) 2, to the Hoek-Brown and MohrCoulomb criteria based on GSI $=40$ and normal shear stress.

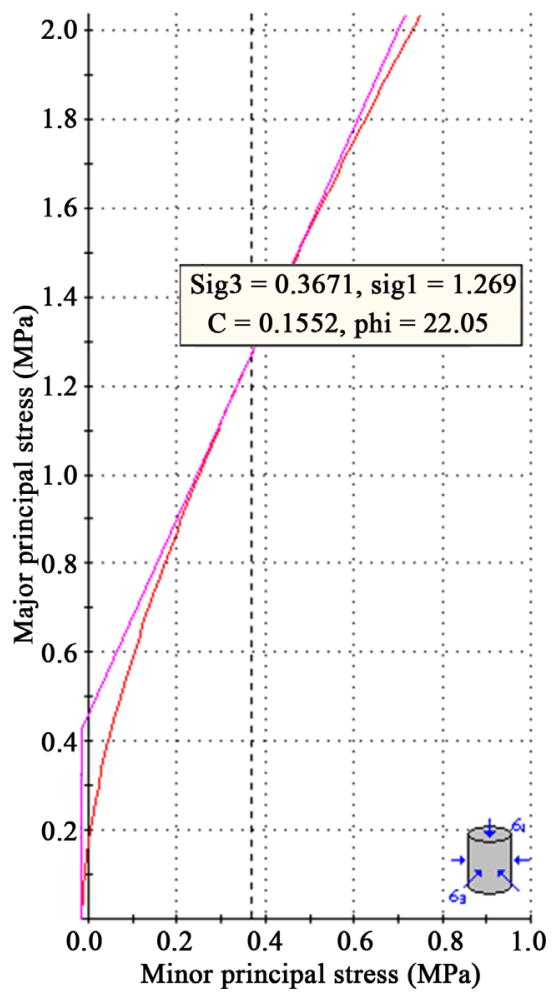

Analysis of Rock Strength using RocLab

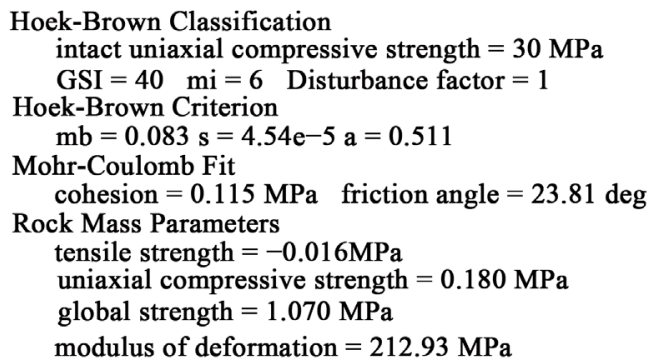

Figure 10. Fitting the data on the rock masses in unit one of the Atamir Formation, K (at) 2, to the Hoek-Brown and MohrCoulomb criteria based on GSI $=40$ and major principal stress. 


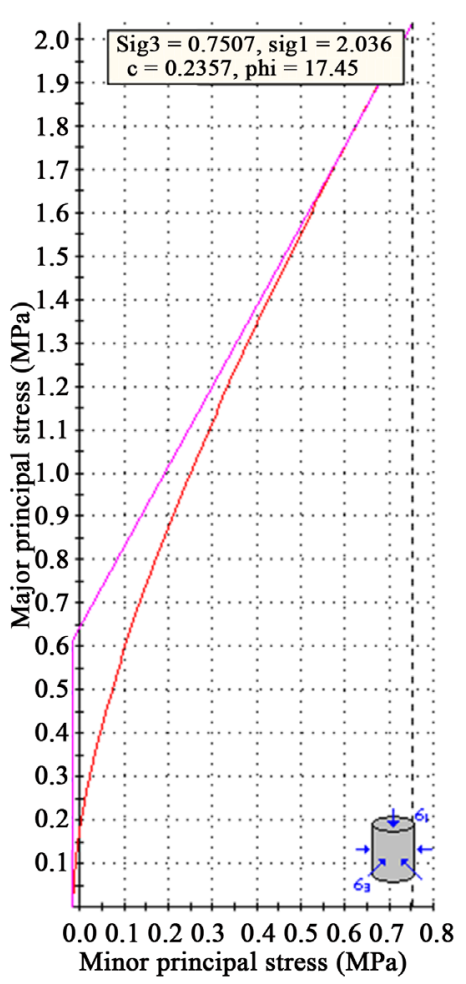

Analysis of Rock Strength using RocLab

Hoek-Brown Classification intact uniaxial compressive strength $=30 \mathrm{MPa}$ $\mathrm{GSI}=40 \mathrm{mi}=6$ Disturbance factor $=1$

Hoek-Brown Criterion

$\mathrm{mb}=0.083 \mathrm{~s}=4.54 \mathrm{e}-5 \mathrm{a}=0.511$

Mohr-Coulomb Fit

cohesion $=0.115 \mathrm{MPa}$ friction angle $=23.81 \mathrm{deg}$

Rock Mass Parameters

tensile strength $=-0.016 \mathrm{MPa}$

uniaxial compressive strength $=0.180 \mathrm{MPa}$

global strength $=1.070 \mathrm{MPa}$

modulus of deformation $=212.93 \mathrm{MPa}$

Figure 11. Analysis of output data for determining geomechanical parameters of the rock masses in unit one based on GSI = 40.



Figure 12. Stereographic images of joint sets.

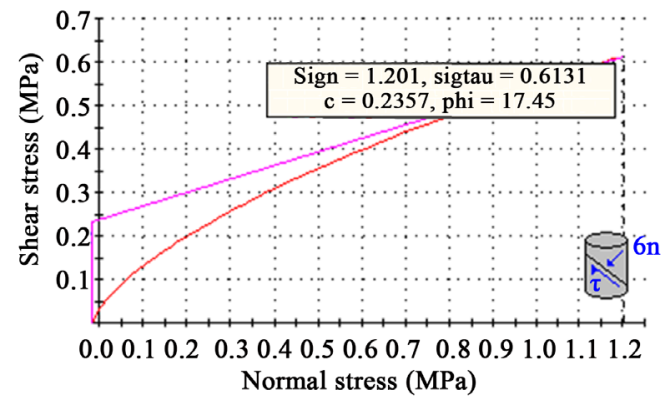




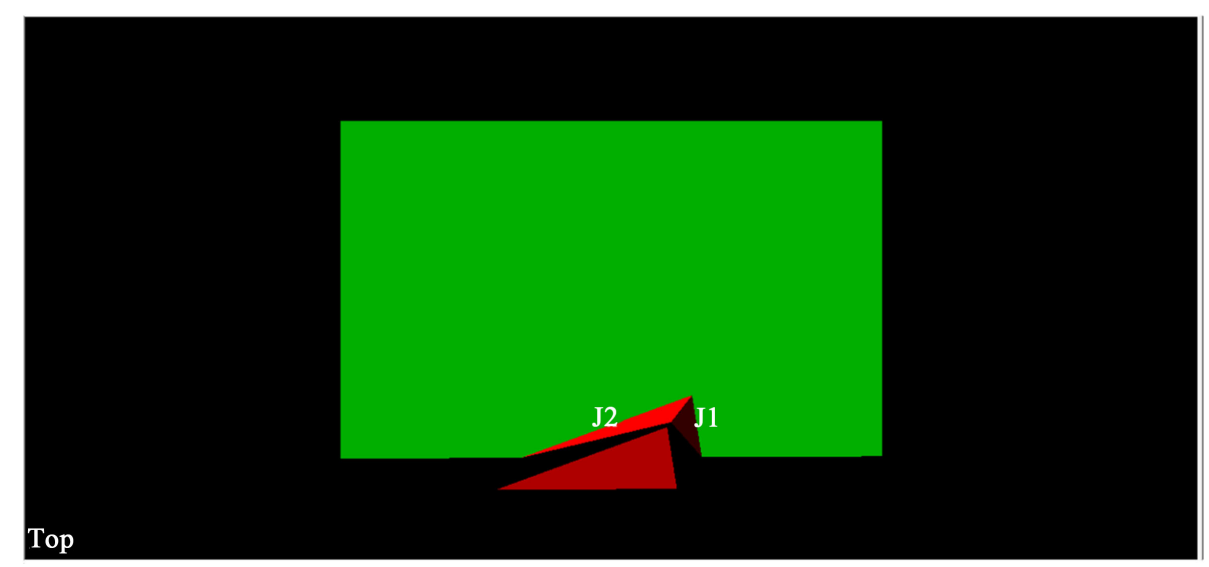

Figure 13. Top view of wedge slide analysis.

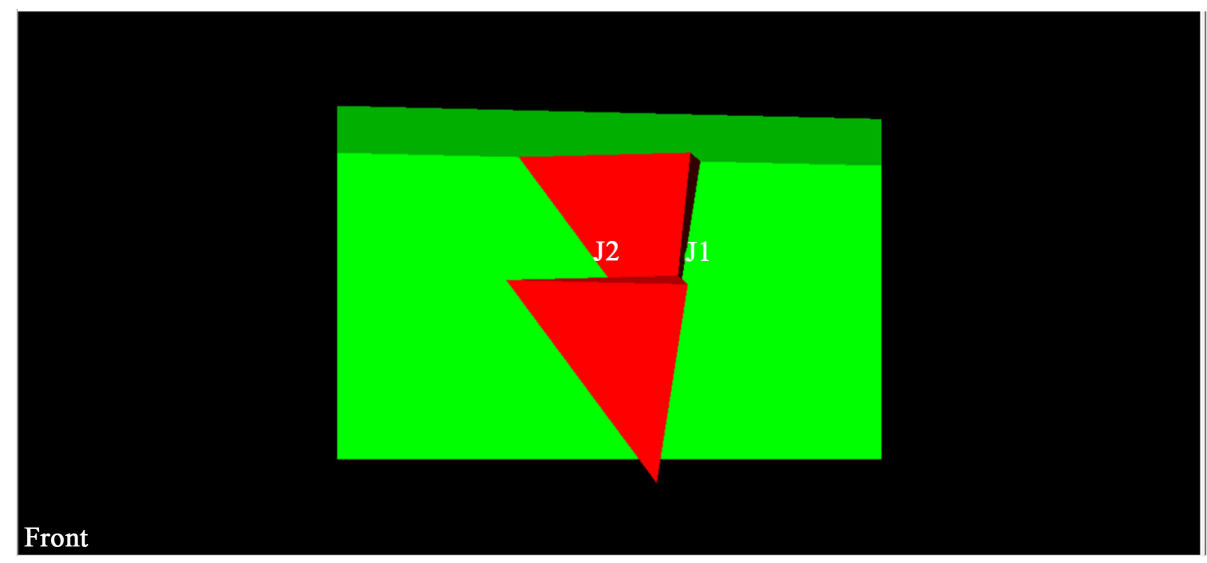

Figure 14. Front view of wedge slide analysis.

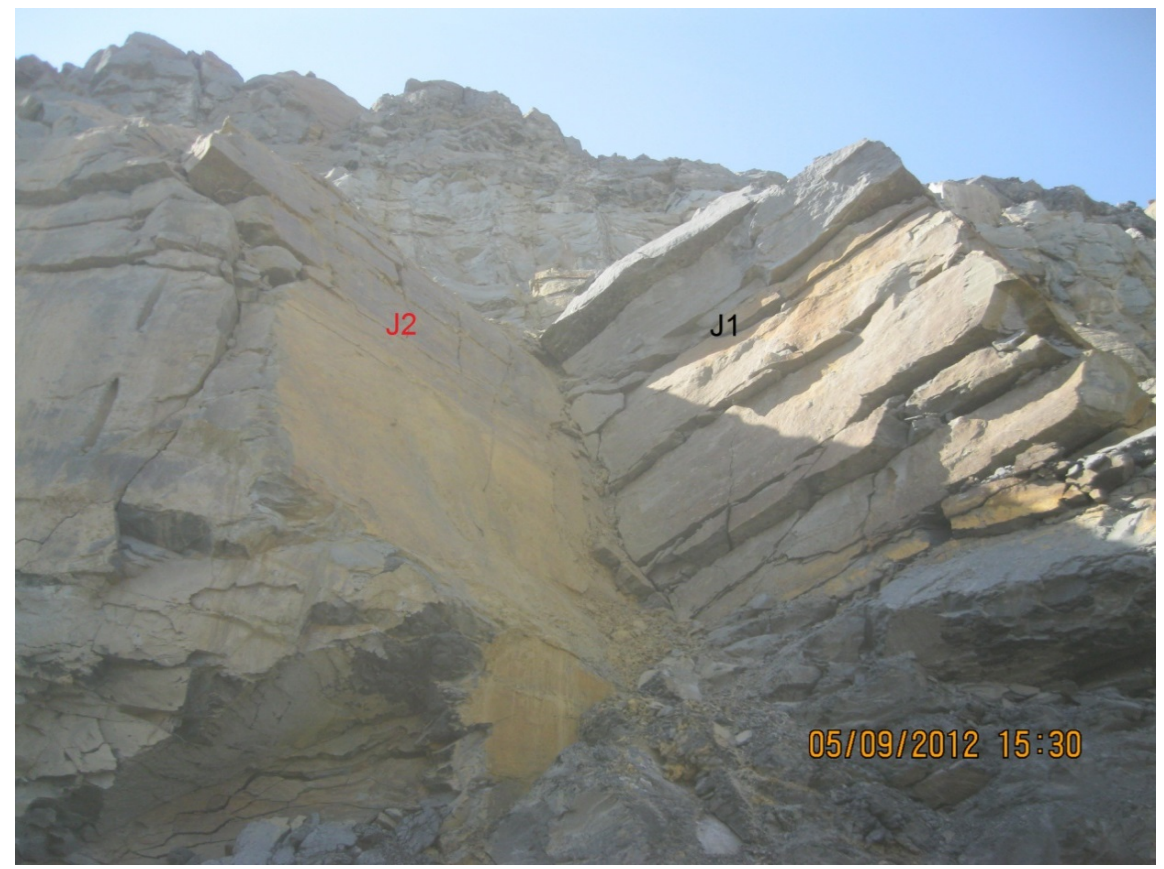

Figure 15. Wedge slide: front view. 


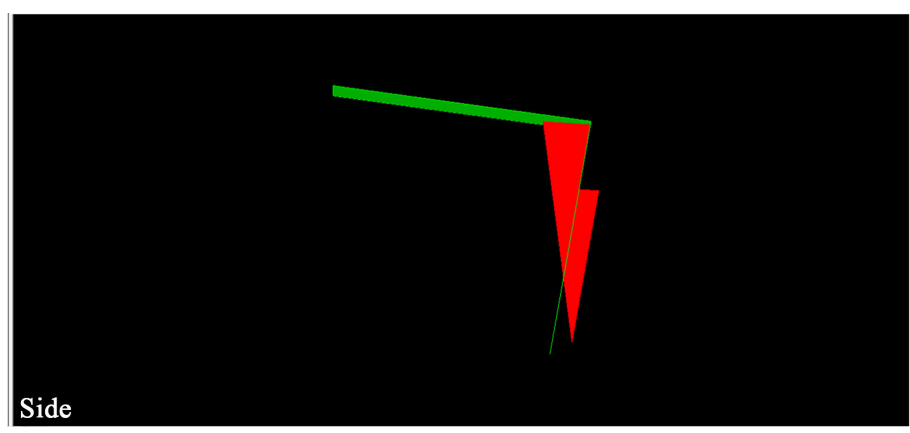

Figure 16. Side view of wedge slide analysis.

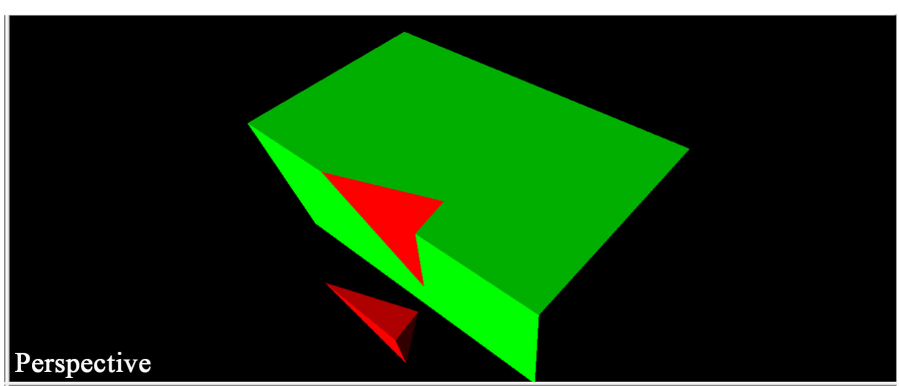

Figure 17. Perspective view of wedge slide analysis.

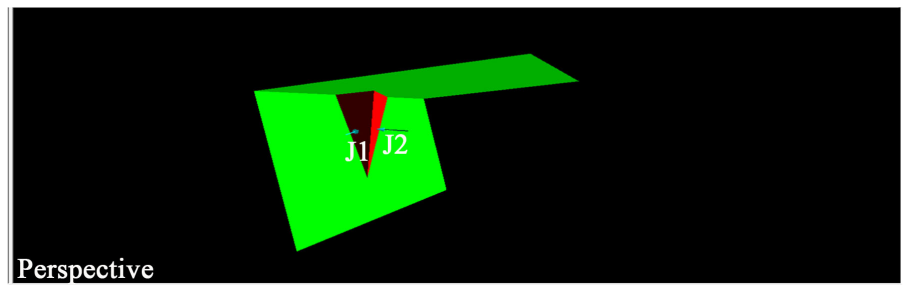

Figure 18. A view of wedge slide analysis obtained by applying directions of water penetration.

Table 5. Geotechnical parameters of the rock masses in unit one of the Atamir Formation K (at) 1.

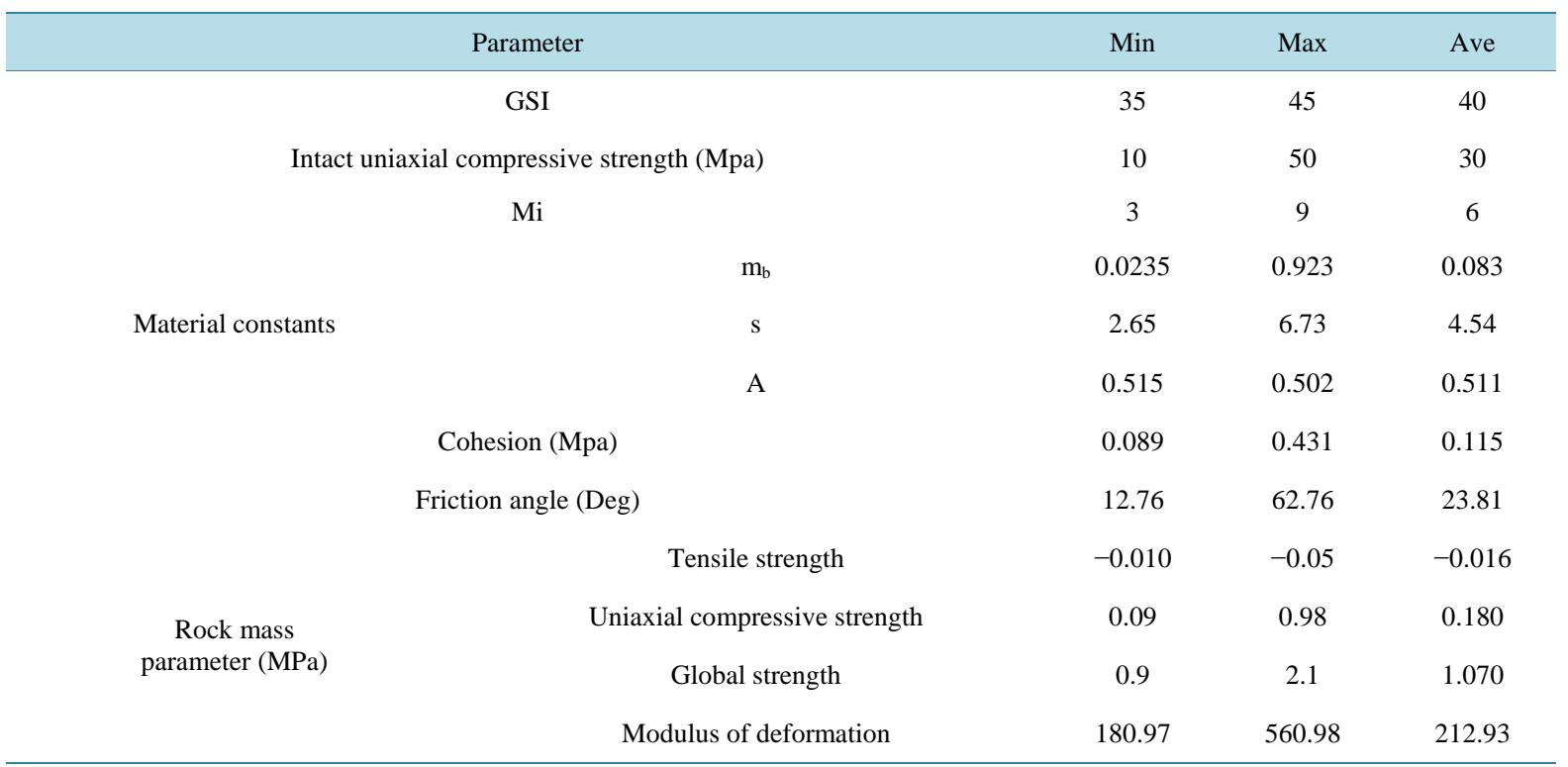




\subsubsection{Analysis of Wedge Instability under Wet Conditions in Unit One of the Atamir} Formation, K (at) 1

Although water is not directly involved in mass (slope) movement, it is an important factor because:

1) Increased water content of slopes caused by rain and snowmelt makes them heavy. Water can penetrate into pores and fractures and replace air and, since water is heavier than air, weights of rocks increase. Because weight is the same as force, and force applies stress on surfaces, increased stress can cause instability.

2) Water can alter slope angle (angle of the slope at which the slope is stable).

3) Water can be absorbed or repelled by soil mineral substances. Water absorption causes the electrical poles of water molecules to stick to the surfaces of mineral materials and penetrate into them. Therefore, increased water content makes rocks heavier, leading to reduced rock strength. In general, wet clay soils have less strength compared to dry clay soils. Therefore, water absorption reduces strength and, since clay is the material that fills the spaces between the joints in this unit, increased water content gains more importance.

4) Groundwater is present almost everywhere under the surface of the ground. This water fills the empty spaces between rock particles and even the cracks within rocks. Groundwater level changes due to rainfall and rises in wet seasons leading to greater water penetration. In dry seasons, groundwater level falls causing less water penetration. These changes in groundwater levels can be an important factor in slope stability.

If water penetrates through joint surfaces, the factor of safety will become zero (FS $=0$ ) (Figure 19).

\subsection{Unit Two of the Atamir Formation, $K$ (at) 2 (from $300+3$ to $500+5$ Meters)}

This lithology includes dark grey sandstones, there are three dominant discontinuity sets in the study region (two joint sets together with bedding), and the discontinuities are random. Table 6 and Table 7 shows the characteristics of the discontinuities. It is shown in Figures 20-22.

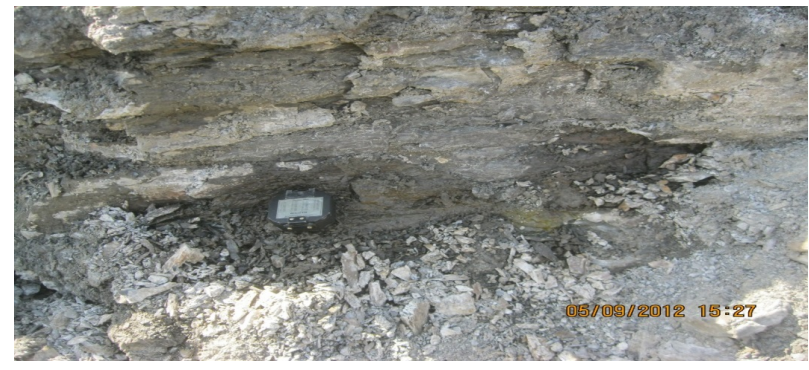

Figure 19. Water penetration into joint sets in unit one of the Atamir Formation.

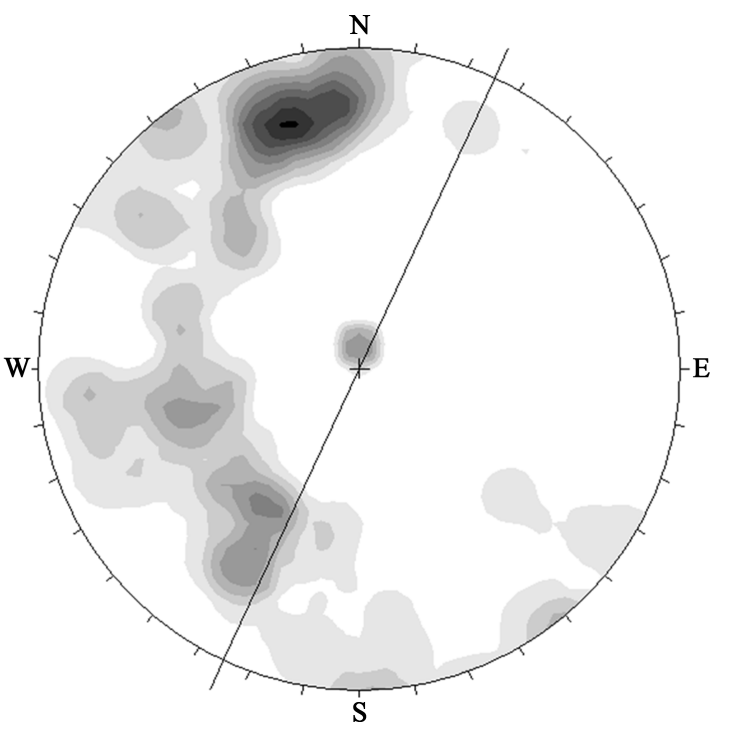

Fisher

Concentrations $\%$ of total per $1.0 \%$ area

$0.00 \%-1.00 \%$

$1.00 \%-2.00 \%$

$2.00 \%-3.00 \%$

$3.00 \%-4.00 \%$

$4.00 \%-5.00 \%$

$5.00 \%-6.00 \%$

$6.00 \%-7.00 \%$

$7.00 \%-8.00 \%$

$8.00 \%-9.00 \%$

$9.00 \%-10.00 \%$

No Bias Correction

Max. Conc. $=9.2208 \%$

Equal Angle

Lower Hemisphere

107 Poles

107 Entries

Figure 20. Stereographic image of the discontinuities in unit two of the Atamir Formation K (at) 2. 


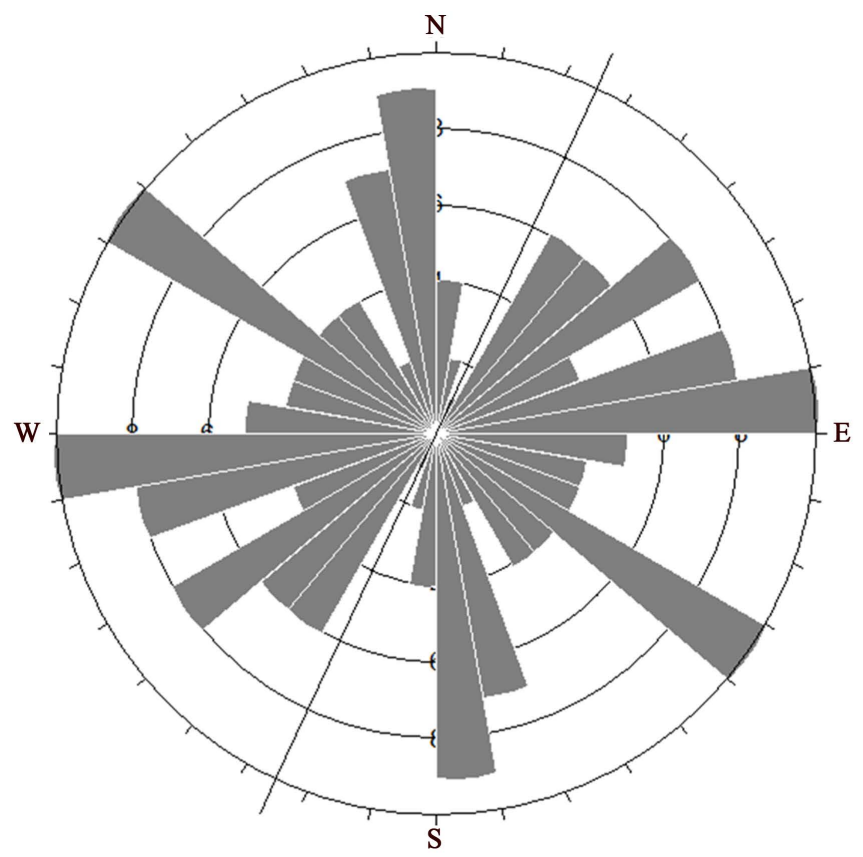

Apparent Strike

10 max planes/arc at outer circle

Trend/Plunge of

Face Normal $=0.90$

(directed away from viewer)

No Bias Correction
100 Planes Plotted
Within 45 and 90
Degrees of Viewing Face

Figure 21. Rose diagram of the discontinuities in unit two of the Atamir Formation K (at) 2.
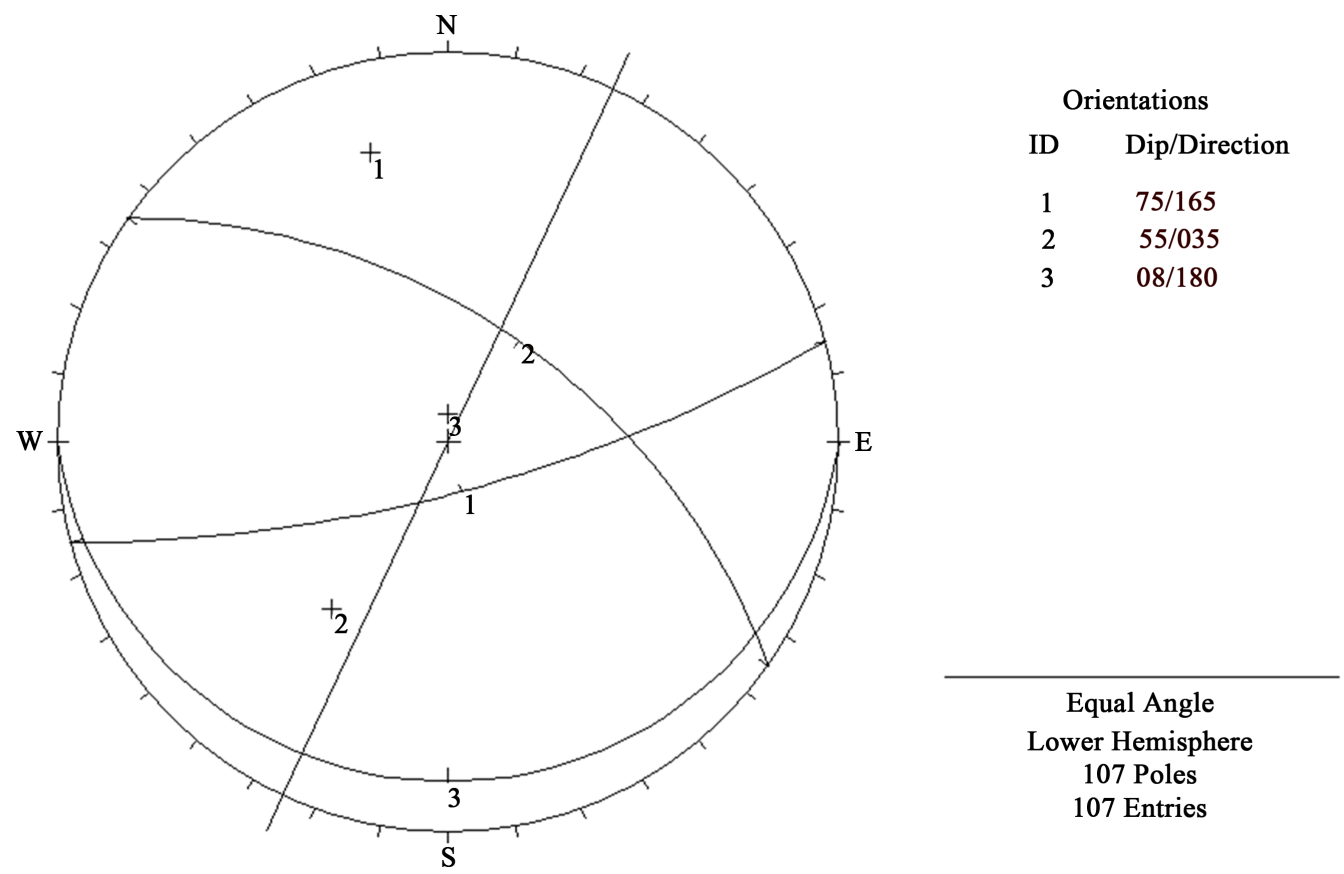

Figure 22. Stereographic image of the discontinuities in unit two of the Atamir Formation K (at) 2.

Table 6. Characteristics of the discontinuities in unit two of the Atamir Formation K (at) 2.

\begin{tabular}{cccc}
\hline Discontinuity & ID & Dip & Dip direction \\
\hline Js1 & 1 & 75 & 165 \\
Js2 & 2 & 55 & 035 \\
Bedding & 3 & 8 & 180 \\
\hline
\end{tabular}


Table 7. Geotechnical characteristics of the various discontinuities in the rock masses of unit two in the Atamir Formation K (at) 2.

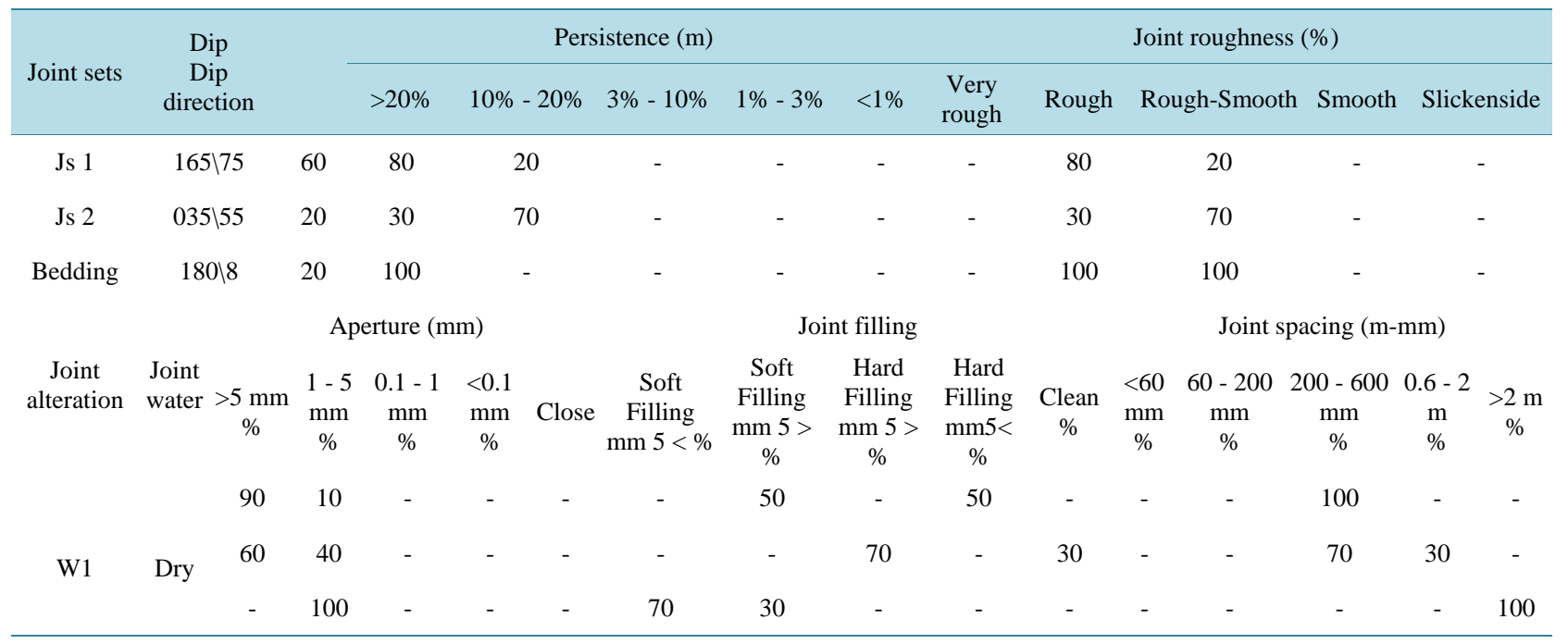

Figures 23-26 show statistical analysis for unit 2.

Tables 8-17 show information of data for the Atamir Formation K (at) 2 like the order of previous zone.

The GSI range of the rock masses in unit two of the Atamir Formation is shown in Figure 27.

Fitting data related to the rock masses in unit two of the Atamir Formation is shown in Figures 28-30.

Stereographic images of joint sets are shown in Figure 31. Wedge slide analysis is also shown in Figures 32-36.

\subsection{Unit Three of the Atamir Formation, K (at) 3 (from $500+3$ to $540+3$ )}

This lithology consists of dark grey sandstones, and there are four dominant discontinuity classes (three joint classes together with bedding) and random discontinuities.

Stereography of the discontinuities is shown in Figure 37-39.

Statistical analysis of discontinuity from Figures 40-43.

Range of GSI in the rock masses of unit three in the Atamir Formation is shown in Figure 44.

Fitting the data on rock masses in unit three is shown in Figures 45-47.

Stereographic images of the joint sets for unit 3 is shown in Figure 48.

Views of wedge slide analysis are shown in Figures 49-53.

\section{Conclusions}

All three units had very poor to poor rocks that required rapid stabilization at most 10 hours after blasting operations. The following geomechanical and geotechnical characteristics were observed:

1) Layered sedimentary rocks sloping towards the outer domain with slopes close or equal to dip slope.

2) Joints and foliations that form weak extended surfaces and intersect the domain surface.

3) Intersecting joints that cause wedge slide failure.

4) Presence of soft, layered, strongly jointed shales having weak layers.

5) Saturation or wetting of joint surfaces having clay filling by water from rainfall, snowmelt, changes in groundwater levels, and reduced frictional force (considering the failure mechanism, and ground surveys, the effects of last spring's rain on the occurrence of this phenomenon cannot be denied).

6) Wet and semi-humid climates and successive snowfalls and, in addition, drought and wet periods.

7) Formations such as marl and shale ones, or intermittent marl and shale formations, are susceptible to mass movements, and the more unsaturated clay fills the joints, the more susceptible the formation will be to mass movement.

8) The tectonic condition (topography) of the dip slope (slopes exceeding 30\%), and slope and orientation of the faults, layers, and fractures.

9) Failure to start stabilization in time according to the RMR table. 


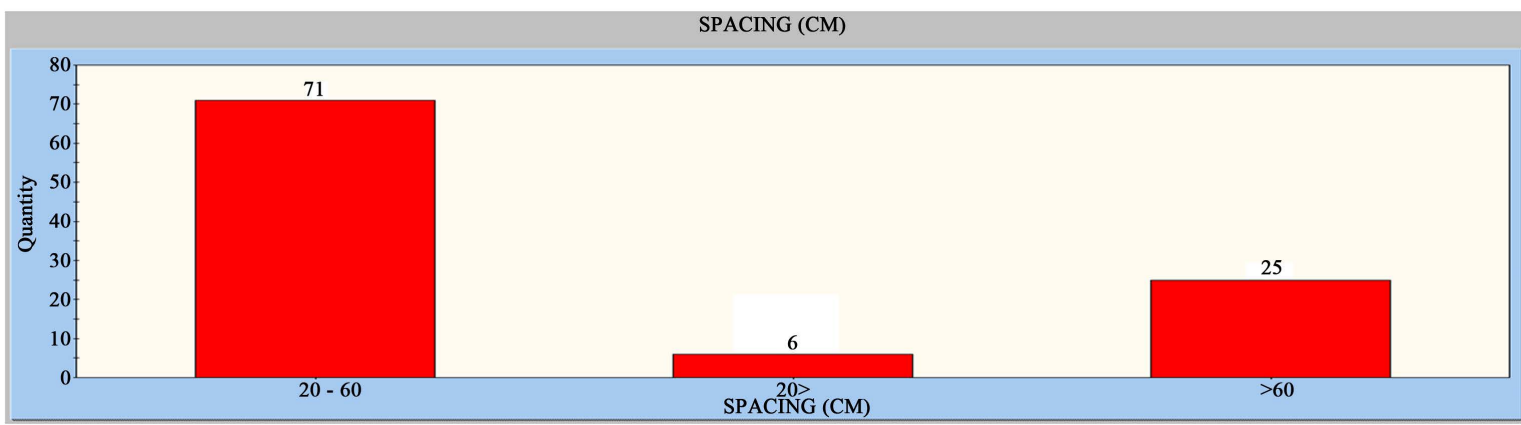

Figure 23. Statistical analysis of discontinuity spacing in unit two of the Atamir Formation K (at) 2.

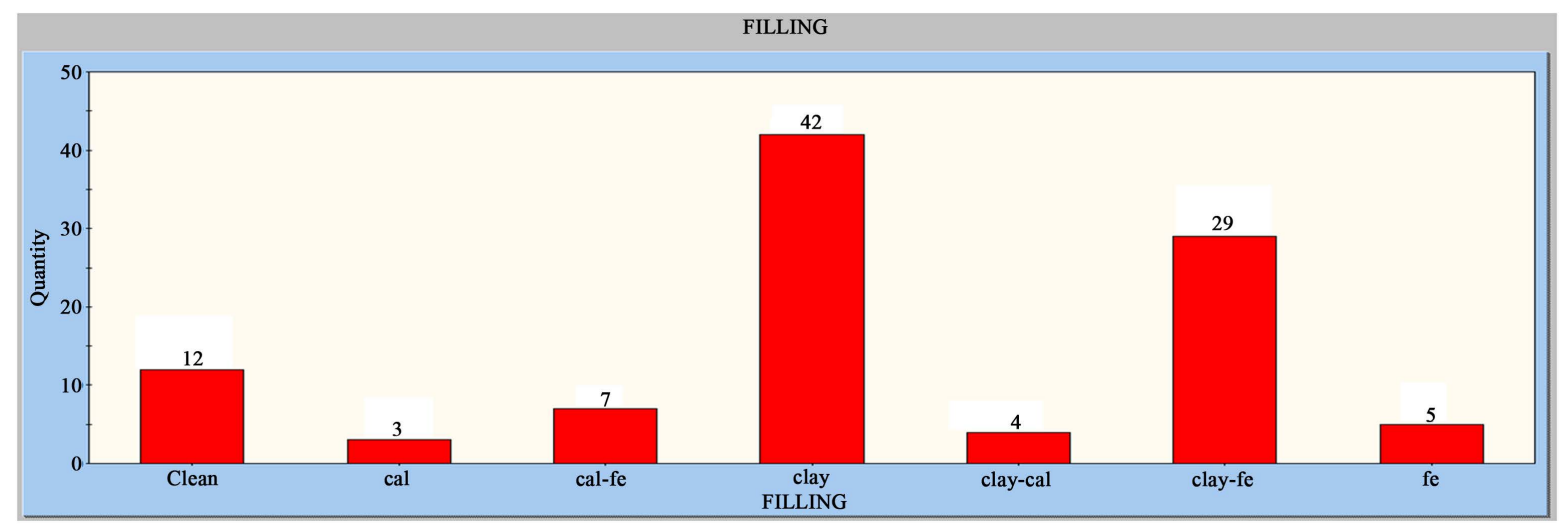

Figure 24. Statistical analysis of discontinuity filling in unit two of the Atamir Formation K (at) 2.

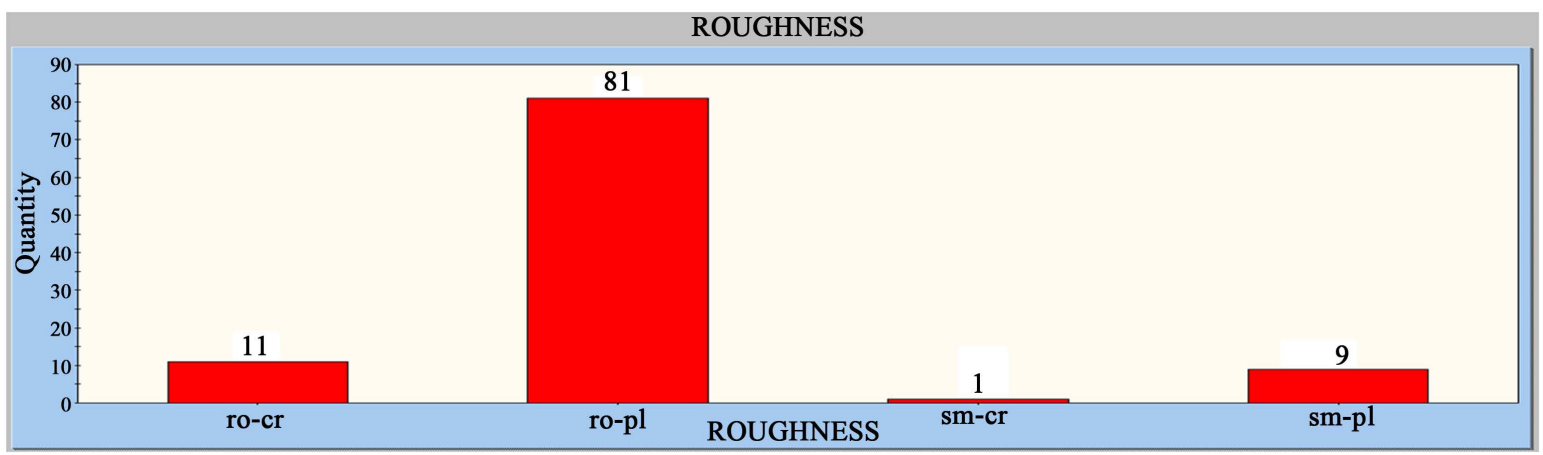

Figure 25. Statistical analysis of discontinuity roughness in unit two of the Atamir Formation K (at) 2.

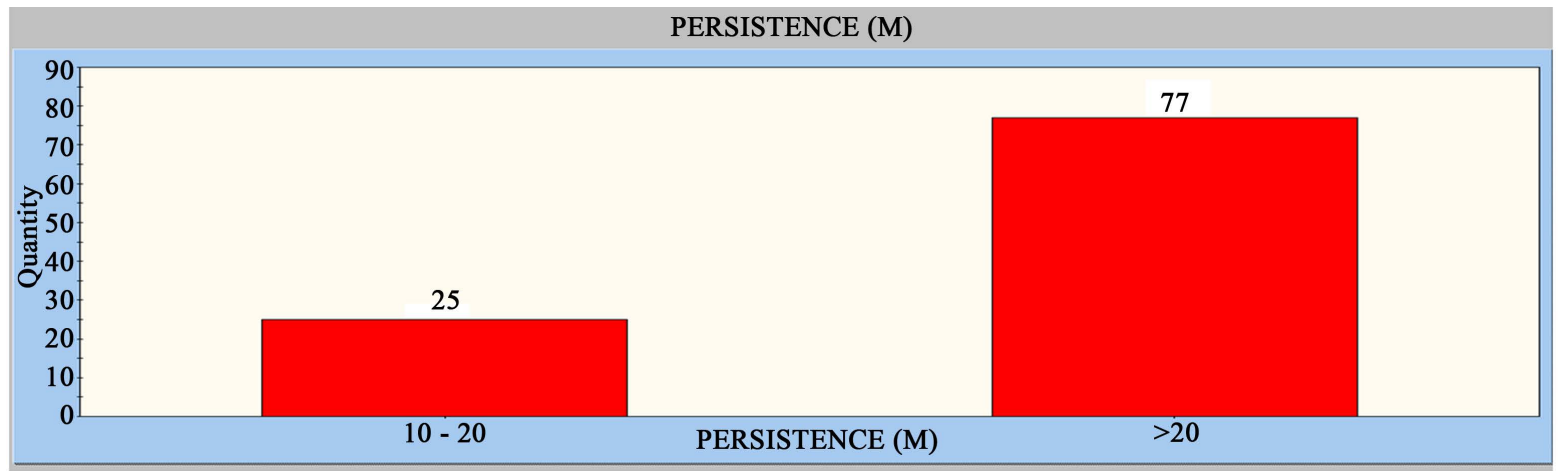

Figure 26. Statistical analysis of discontinuity orientations in unit two of the Atamir Formation K (at) 2. 
Geological Strength Index

From the description of structure and surface conditions of the rock mass, pick an appropriate box in this chart Estimate the average value to the Geological Strength Index (GSI) from the contours. Do not attempt to be too precise. Quoting a range of GSI from 36 to 42 is more realistic than stating that GSI $=38$. It is also important to recognize that the Hoek-Brown criterion should only be applied to rock masses where the size of individual blocks is small compared with the size of the excavation under consideration.

Structure

Blocky-very well interlocked undisturbed rock mass consisting of cubical blocks formed by three orthogonal discontinuity sets

Very Blocky-interlocked, partially disturbed rock mass with multifaceted angular blocks formed by four or more discontinuity sets

Blocky/disturbed-folded and/or faulted with angular blocks formed by

many intersecting discontinuity sets

Disintegrated-poorly interlocked, heavily broken rock mass with a mixture of angular and rounded rock pieces

Foliated/laminated/sheard-thinly laminated or foliated, tectonically sheared weak rocks or foliated, tectonically sheared weak rocks;
closely spaced schistosity prevails over any other discontinuity set, resulting in complete lack of blockiness

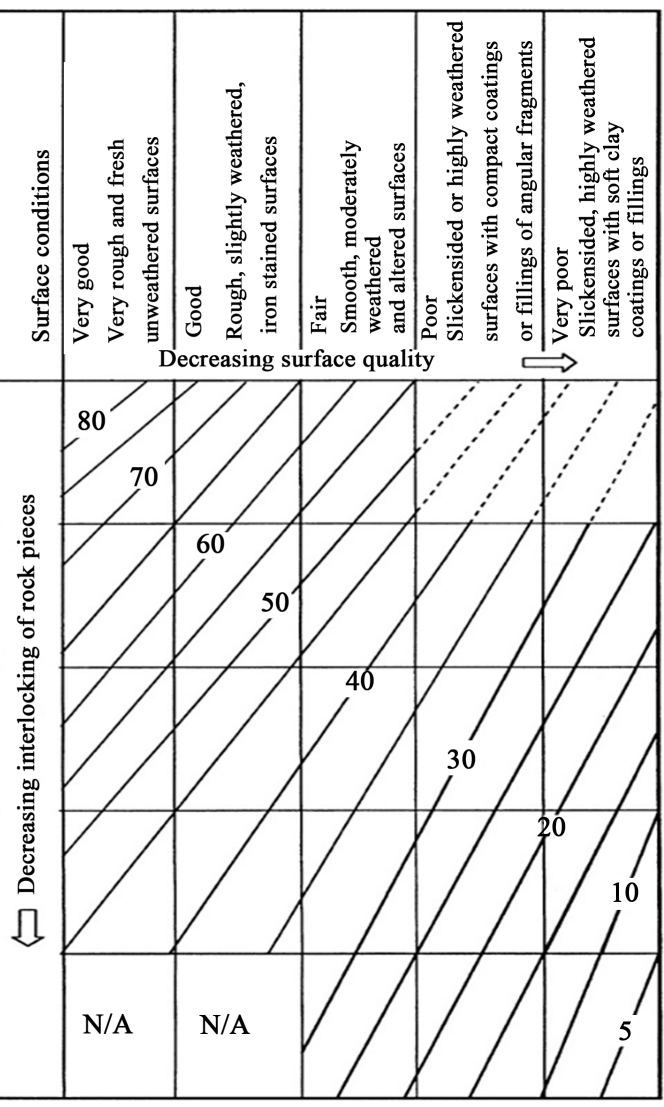

Figure 27. The GSI range of the rock masses in unit two of the Atamir Formation K (at) 2 in the GSI classification diagram.

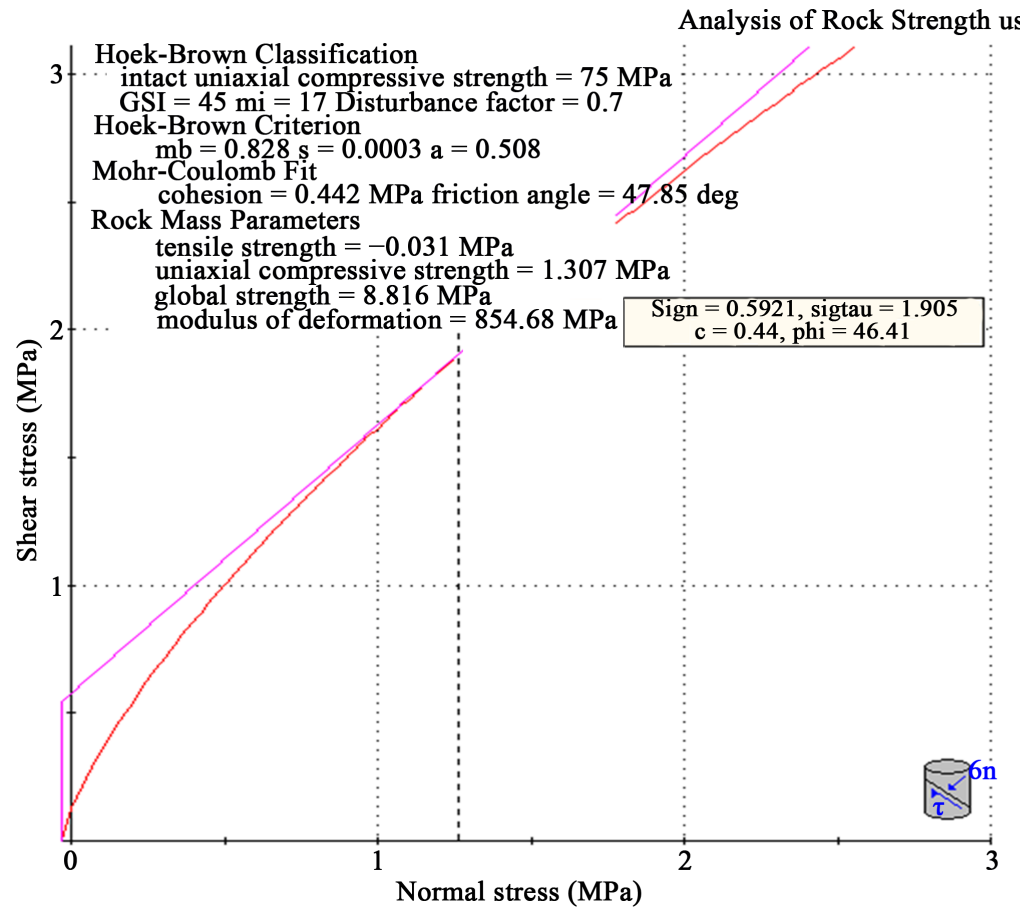

Figure 28. Fitting data related to the rock masses in unit two of the Atamir Formation, K (at) 2, to Hoek-Brown and MohrCoulomb criteria. 


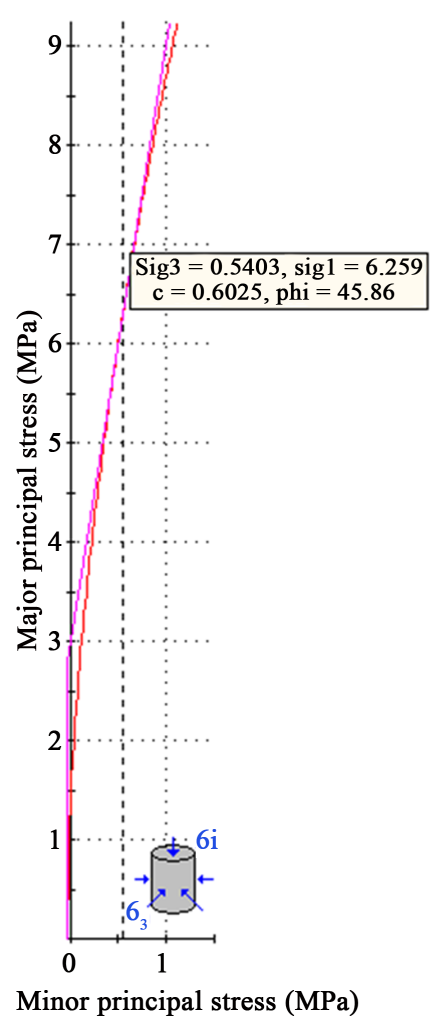

Analysis of Rock Strength using RocLab

Hoek-Brown Classification

intact uniaxial compressive strength $=75 \mathrm{MPa}$

$\mathrm{GSI}=45 \mathrm{mi}=17$ Disturbance factor $=0.7$

Hoek-Brown Criterion

$\mathrm{mb}=0.828 \mathrm{~s}=0.0003 \mathrm{a}=0.508$

Mohr-Coulomb Fit

cohesion $=0.442 \mathrm{MPa}$ friction angle $=47.85 \mathrm{deg}$

Rock Mass Parameters

tensile strength $=-0.031 \mathrm{MPa}$

uniaxial compressive strength $=1.307 \mathrm{MPa}$

global strength $=8.816 \mathrm{MPa}$

modulus of deformation $=854.68 \mathrm{MPa}$

Figure 29. Fitting the data related to the rock masses of unit two to the Hoek-Brown and Mohr-Coulomb criteria based on GSI $=45$ and on major principal stress.

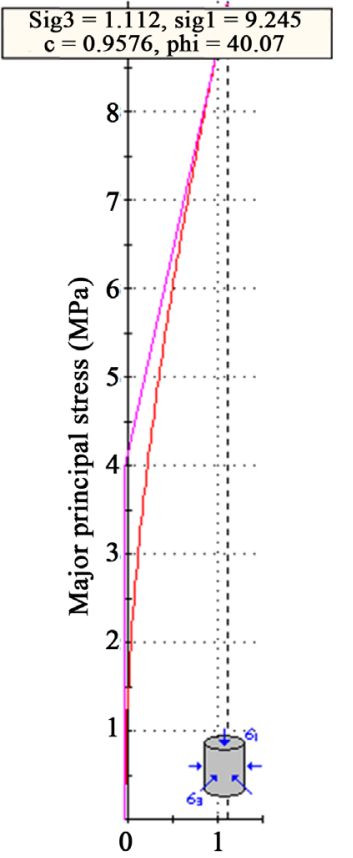

Minor principal stress (MPa)
Analysis of Rock Strength using RocLab

Hoek-Brown Classification intact uniaxial compressive strength $=75 \mathrm{MPa}$ $\mathrm{GSI}=45 \mathrm{mi}=17$ Disturbance factor $=0.7$

Hoek-Brown Criterion $\mathrm{mb}=0.828 \mathrm{~s}=0.0003 \mathrm{a}=0.508$

Mohr-Coulomb Fit

cohesion $=0.442 \mathrm{MPa}$ friction angle $=47.85 \mathrm{deg}$

Rock Mass Parameters

tensile strength $=-0.031 \mathrm{MPa}$

uniaxial compressive strength $=1.307 \mathrm{MPa}$

global strength $=8.816 \mathrm{MPa}$

modulus of deformation $=854.68 \mathrm{MPa}$

Figure 30. Analysis of output data determining geomechanical parameters of the rock masses in unit two based on GSI $=45$. 


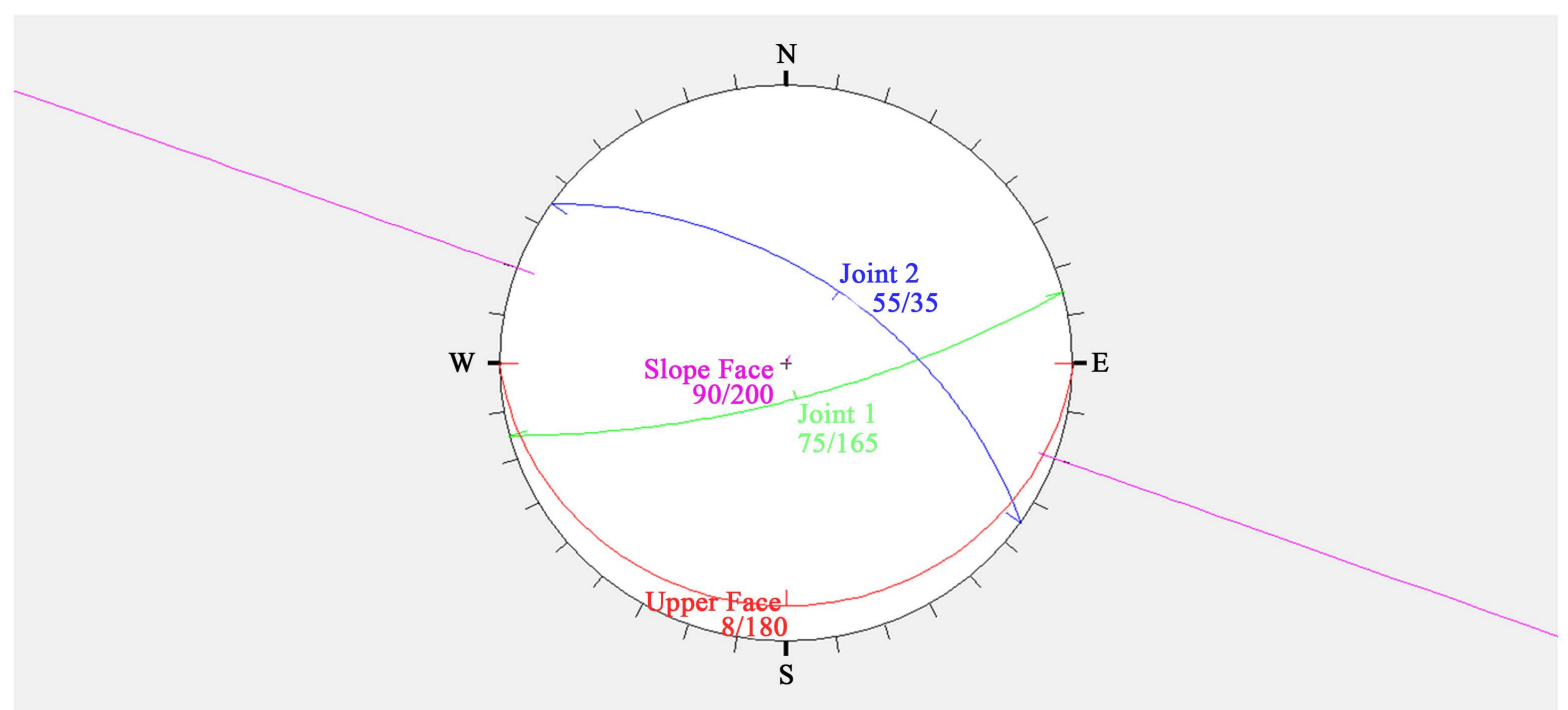

Figure 31. Stereographic images of joint sets.

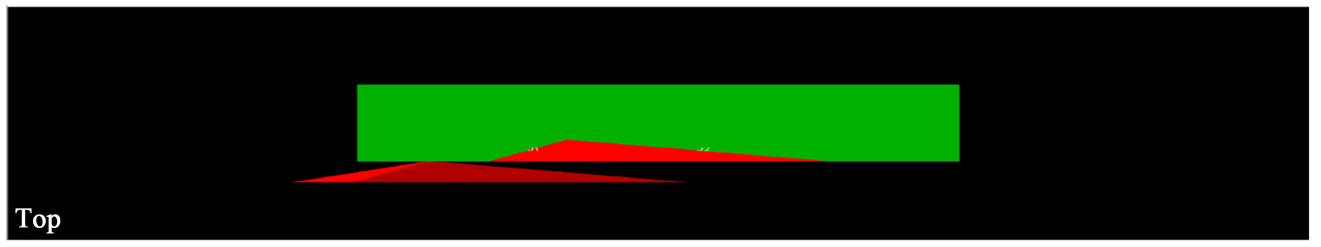

Figure 32. Top view of wedge slide analysis.

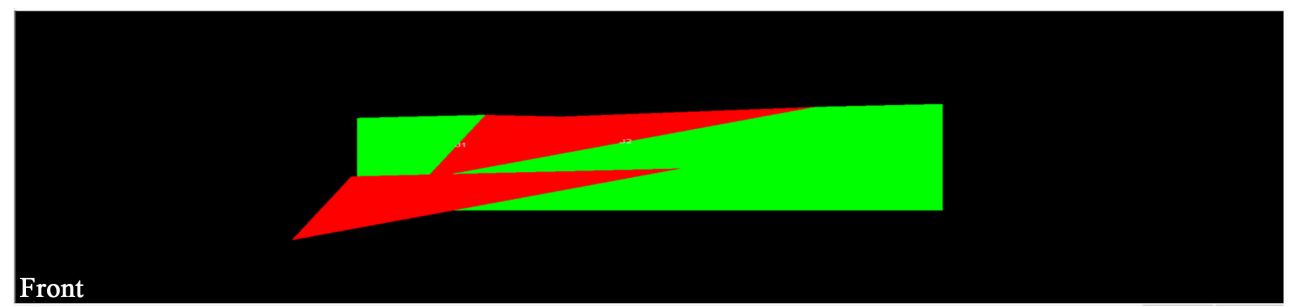

Figure 33. Front view of wedge slide analysis.

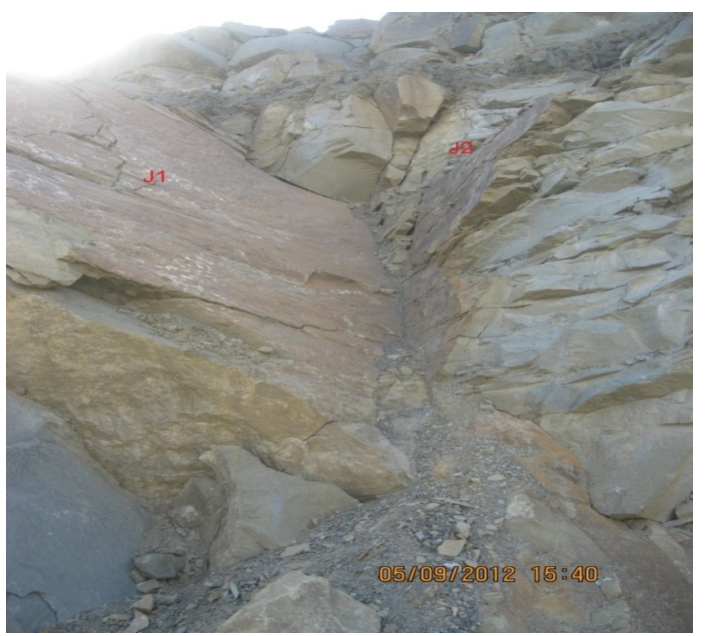

Figure 34. Front view of wedge slide. 


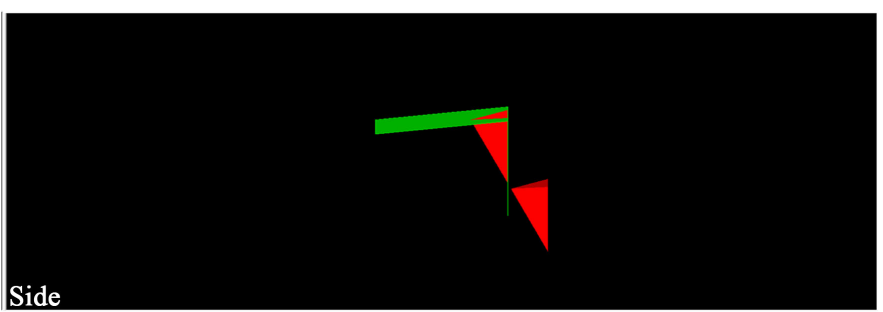

Figure 35. Side view of wedge slide analysis.

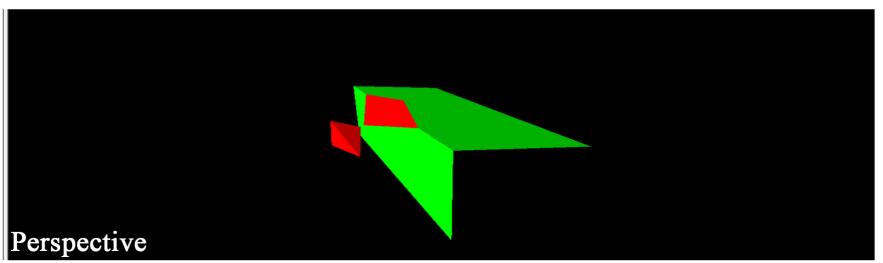

Figure 36. Perspective view of wedge slide analysis.

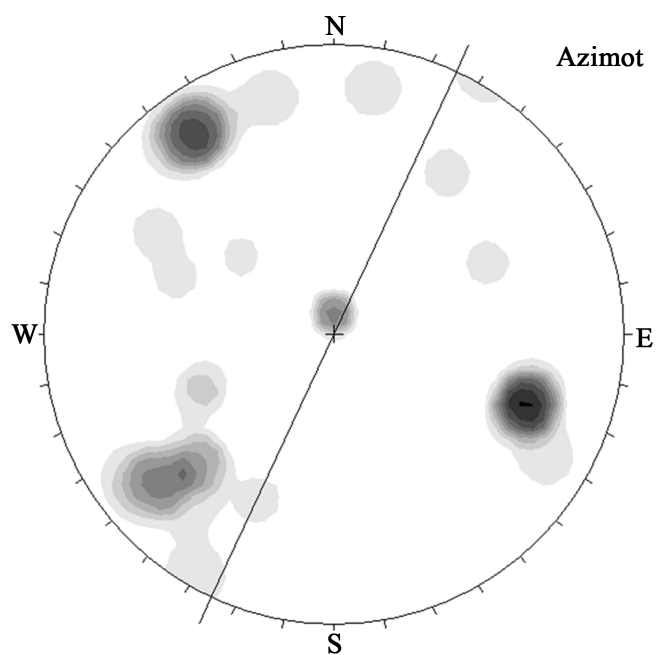

Fisher

Concentrations

$\%$ of total per $1.0 \%$ area

$0.00 \%-2.00 \%$

$2.00 \%-4.00 \%$

$4.00 \%-6.00 \%$

$6.00 \%-8.00 \%$

$8.00 \%-10.00 \%$

$10.00 \%-12.00 \%$

$12.00 \%-14.00 \%$

$14.00 \%-16.00 \%$

$16.00 \%-18.00 \%$

$18.00 \%-20.00 \%$

No Bias Correction

Max. Conc. $=18.2453 \%$

Equal Angle
Lower Hemisphere
37 Poles
37 Entries

Figure 37. Stereographic image of the discontinuities in unit three of the Atamir Formation K (at) 3.

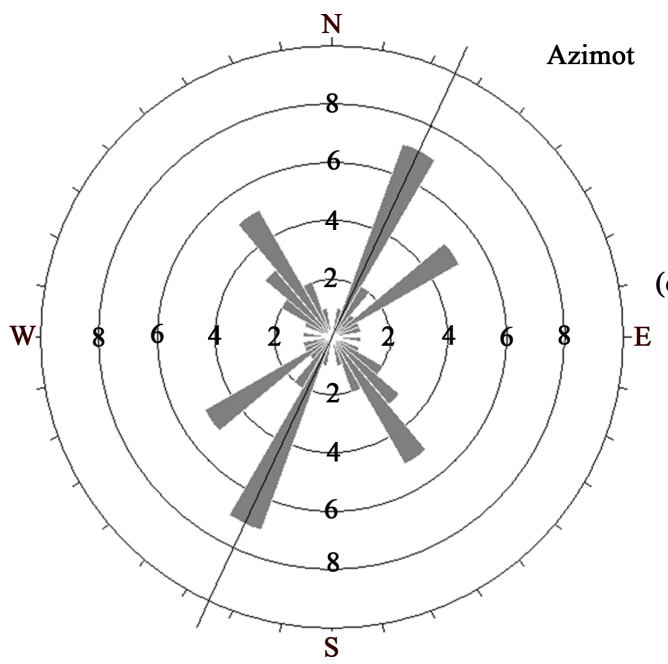

Apparent Strike

10 max planes/arc at outer circle

Trend/Plunge of

Face Normal $=0.90$ (directed away from viewer)

No Bias Correction

33 Planes Plotted

Within 45 and 90

Degrees of Viewing

Face

Figure 38. Rose diagram of the discontinuities in unit three of the Atamir Formation K (at) 3. 

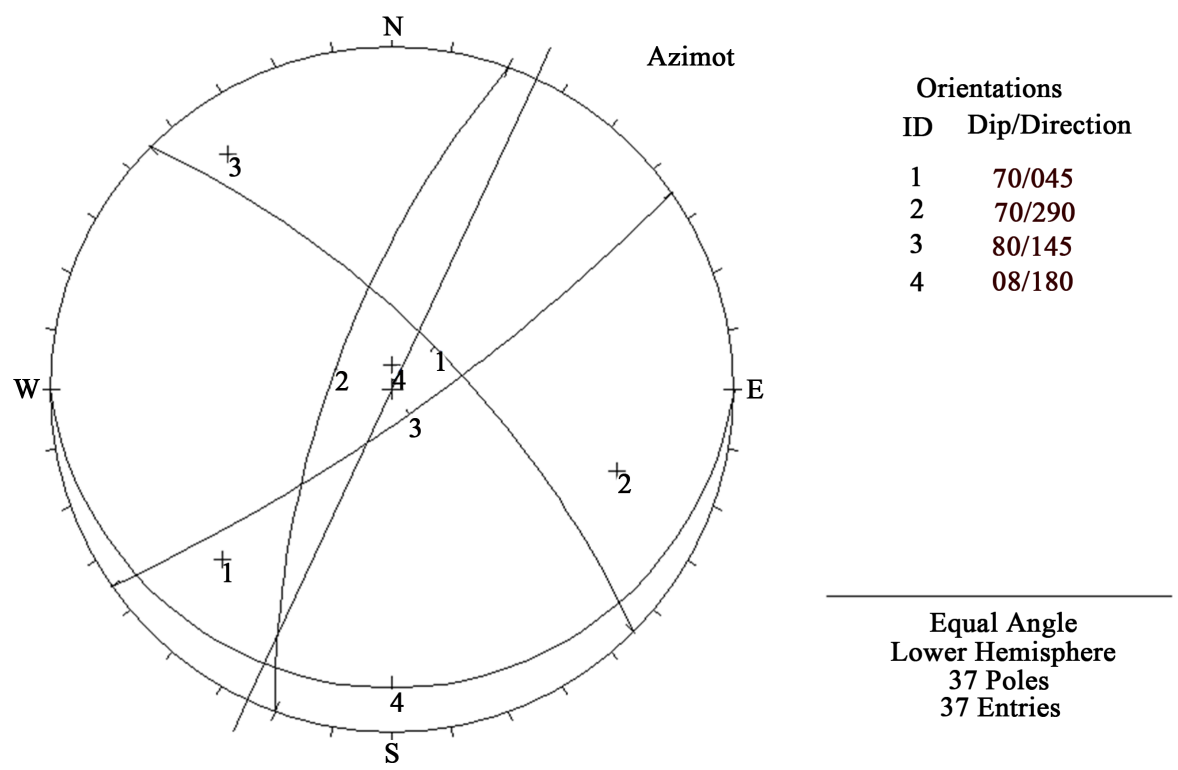

Figure 39. Stereography of the discontinuities in unit three of the Atamir Formation K (at) 3.



Figure 40. Statistical analysis of discontinuity spacings in unit three of the Atamir Formation K (at) 3.

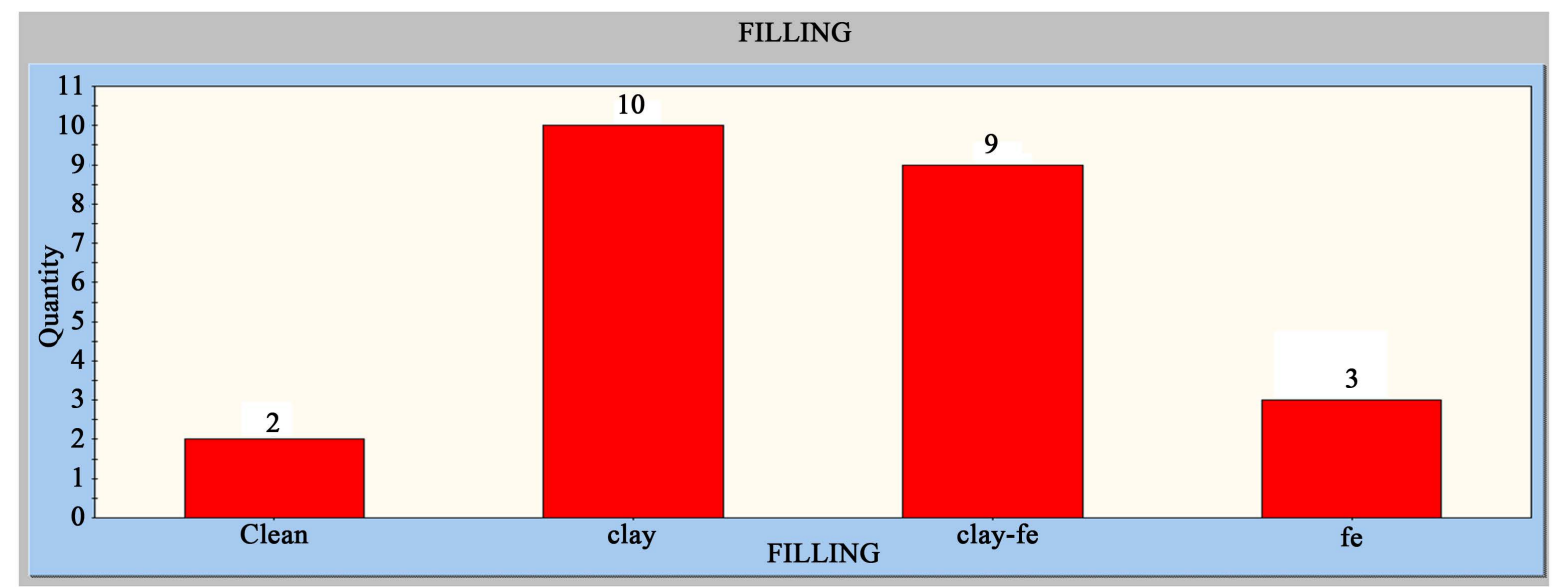

Figure 41. Statistical analysis of discontinuity filling in unit three of the Atamir Formation K (at) 3. 




Figure 42. Statistical analysis of discontinuity roughness in unit three of the Atamir Formation K (at) 3.

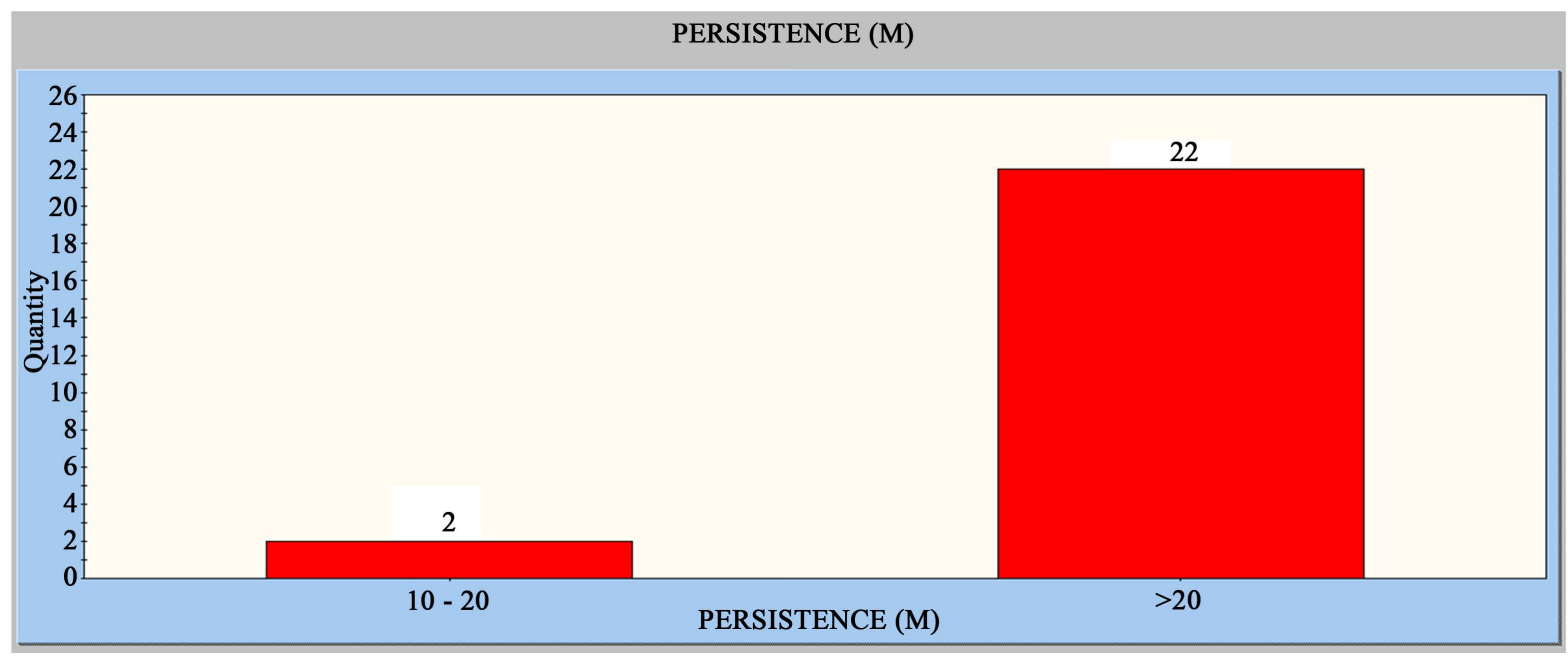

Figure 43. Statistical analysis of discontinuity orientation in unit three of the Atamir Formation K (at) 3.

Table 8. Geomechanical classification of the rock masses in unit two of the Atamir Formation K (at) 2.

\begin{tabular}{ccc}
\hline Parameter & Value & Rating \\
UCS (MPa) & $40-60$ & $4-6$ \\
RQD & $25-50$ & 8 \\
Spacing (MM) & $60-200$ & $8-10$ \\
Condition of discontinuities & Dam & 70 \\
Groundwater & $37-41$ \\
RMR & Dam \\
Class No. & 442 \\
Cohesion of the rock mass (KPa) & $15-25$ \\
\hline
\end{tabular}


Geological Strength Index

From the description of structure and surface conditions of the rock mass, pick an appropriate box in this chart. Estimate the average value to the Geological Strength Index (GSI) from the contours. Do not attempt to be too precise. Quoting a range of GSI from 36 to 42 is more realistic than stating that GSI $=38$. It is also important to recognize that the Hoek-Brown criterion should only be applied to rock masses where the size of individual blocks is small compared with the size of the excavation under consideration.



well interlocked undisturbed rock mass consisting of cubical blocks formed by three orthogonal discontinuity sets

Very Blocky-interlocked, partially disturbed rock mass with multifaceted angular blocks formed by four or more discontinuity sets

Blocky/disturbed-folded and/or faulted with angular blocks formed by many intersecting discontinuity sets

Disintegrated-poorly interlocked, heavily broken rock mass with a mixture of angular and rounded rock pieces

Foliated/laminated/sheard-thinly laminated or foliated, tectonically sheared weak rocks; closely spaced schistosity prevails over any other discontinuity set, resulting in complete lack of blockiness

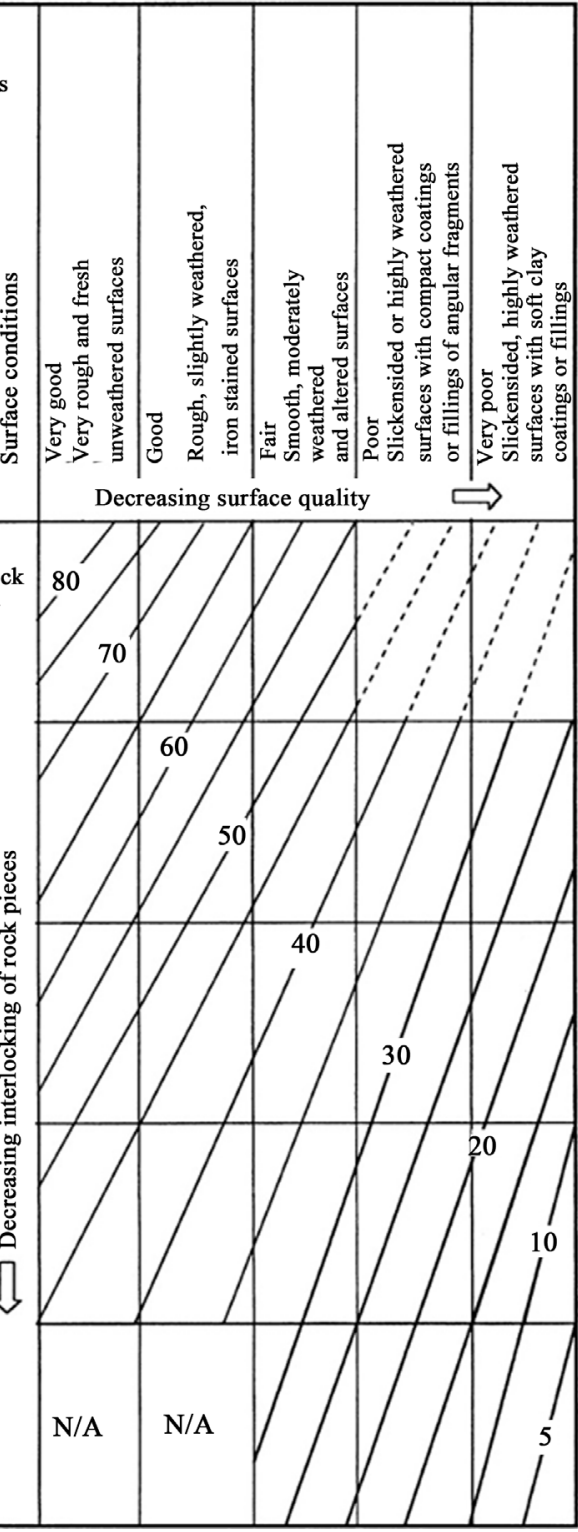

Figure 44. Range of GSI in the rock masses of unit three in the Atamir Formation K (at) 3.

Table 9. The Q index of the rock masses in unit two of the Atamir Formation K (at) 2.

\begin{tabular}{ccc}
\hline Parameter & Description & Value \\
\hline RQD & $40-50$ & $40-45$ \\
$\mathrm{~J}_{\mathrm{n}}$ & Three joint sets with random to four joint sets & 12 \\
$\mathrm{~J}_{\mathrm{r}}$ & Smooth to planar & 4 \\
$\mathrm{~J}_{\mathrm{a}}$ & Softening or low friction clay mineral coatings & $1-0.66$ \\
$\mathrm{~J}_{\mathrm{w}}$ & Dry to medium inflow of pressure & 1 \\
$\mathrm{SRF}$ & Medium stress, favorable stress condition & $0.62-0.83$ \\
$\mathrm{Q}$ & & Very poor rock
\end{tabular}




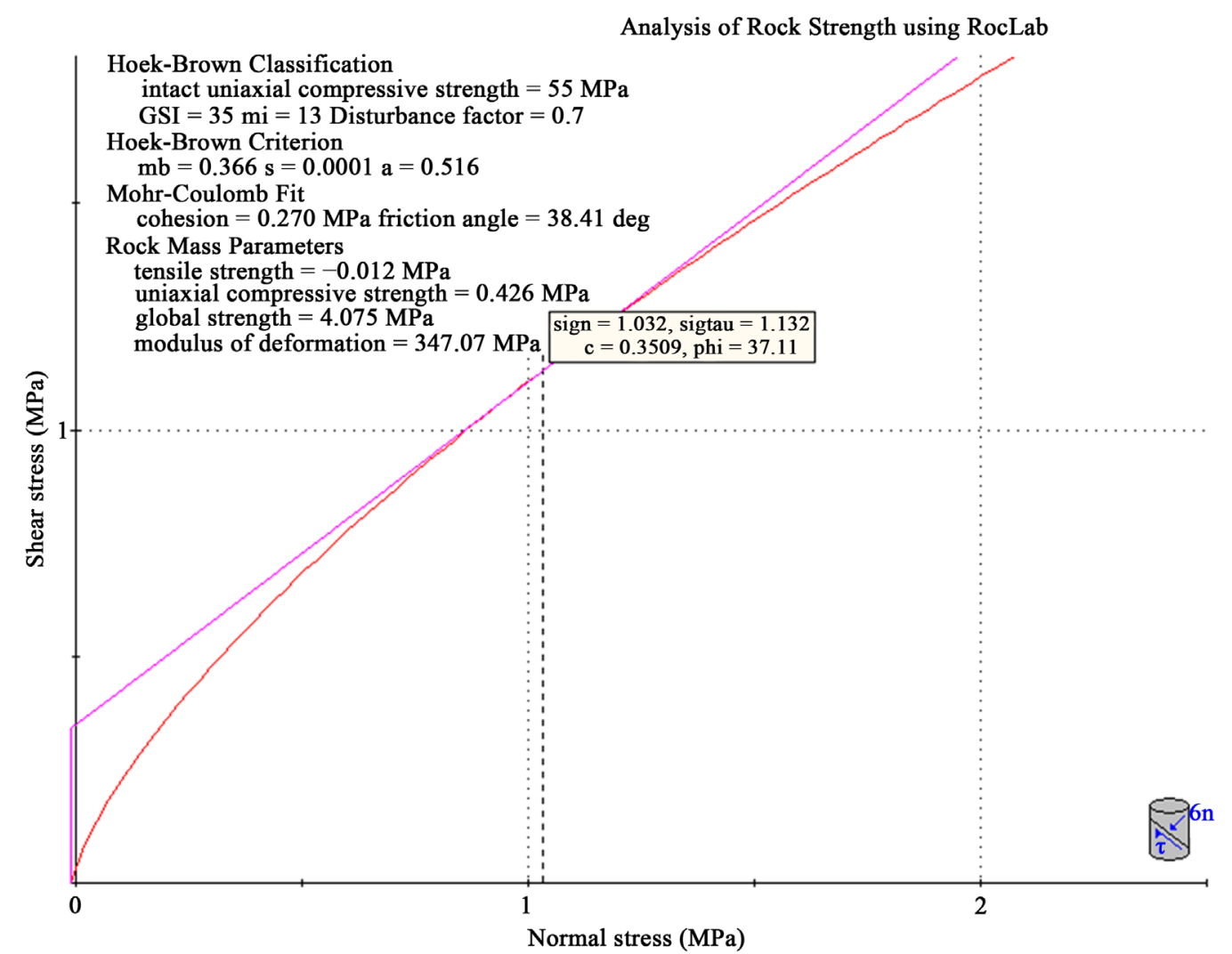

Figure 45. Fitting the data on rock masses in unit three to the Hoek-Brown and Mohr-Coulomb criteria, based on GSI = 35 and on normal shear stress.

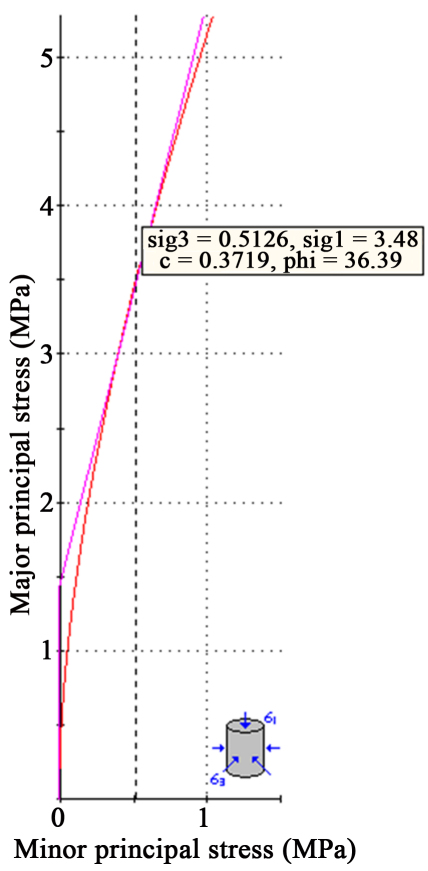

Analysis of Rock Strength using RocLab

Hoek-Brown Classification intact uniaxial compressive strength $=55 \mathrm{MPa}$

GSI $=35 \mathrm{mi}=13$ Disturbance factor $=0.7$

Hoek-Brown Criterion

$\mathrm{mb}=0.366 \mathrm{~s}=0.0001 \mathrm{a}=0.516$

Mohr-Coulomb Fit

cohesion $=0.270 \mathrm{MPa}$ friction angle $=38.41 \mathrm{deg}$

Rock Mass Parameters

tensile strength $=-0.012 \mathrm{MPa}$

uniaxial compressive strength $=0.426 \mathrm{MPa}$

global strength $=4.075 \mathrm{MPa}$

modulus of deformation $=347.07 \mathrm{MPa}$

Minor principal stress (MPa)

Figure 46. Fitting the data on rock masses in unit three to the Hoek-Brown and Mohr-Coulomb criteria, based on GSI = 35 and on major principal stress. 


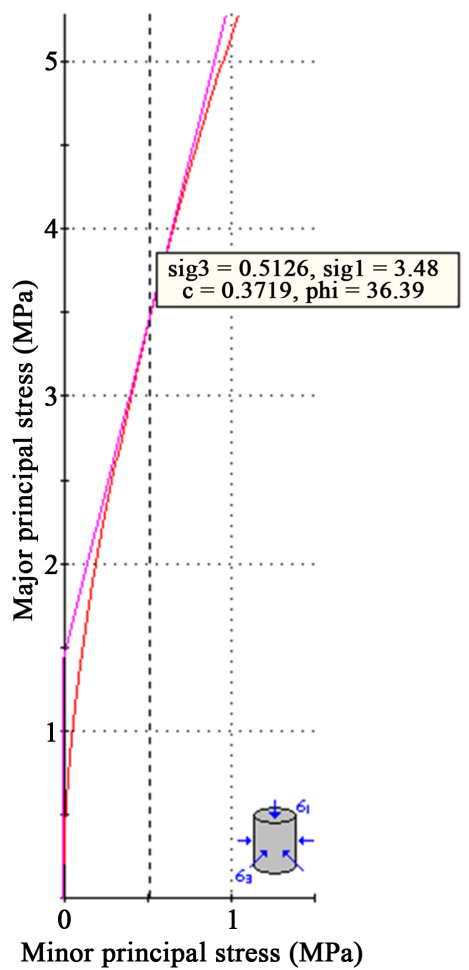

Analysis of Rock Strength using RocLab

$$
\text { Hoek-Brown Classification }
$$

intact uniaxial compressive strength $=55 \mathrm{MPa}$

$\mathrm{GSI}=35 \mathrm{mi}=13$ Disturbance factor $=0.7$

Hoek-Brown Criterion

$\mathrm{mb}=0.366 \mathrm{~s}=0.0001 \mathrm{a}=0.516$

Mohr-Coulomb Fit

cohesion $=0.270 \mathrm{MPa}$ friction angle $=38.41 \mathrm{deg}$

Rock Mass Parameters

tensile strength $=-0.012 \mathrm{MPa}$

uniaxial compressive strength $=0.426 \mathrm{MPa}$

global strength $=4.075 \mathrm{MPa}$

modulus of deformation $=347.07 \mathrm{MPa}$

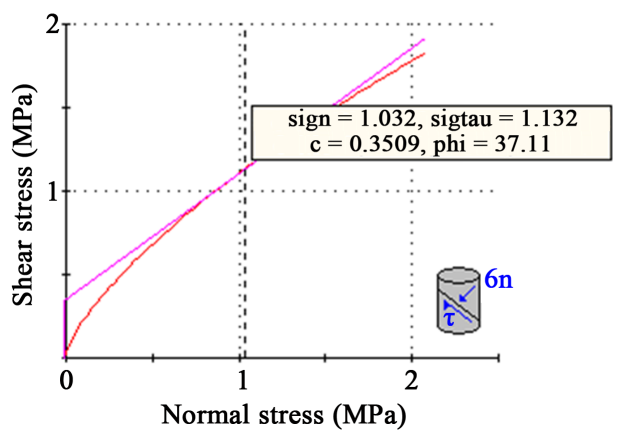

Figure 47. Analysis of output data determining the geomechanical parameters of rock masses in unit three, based on GSI = 35.

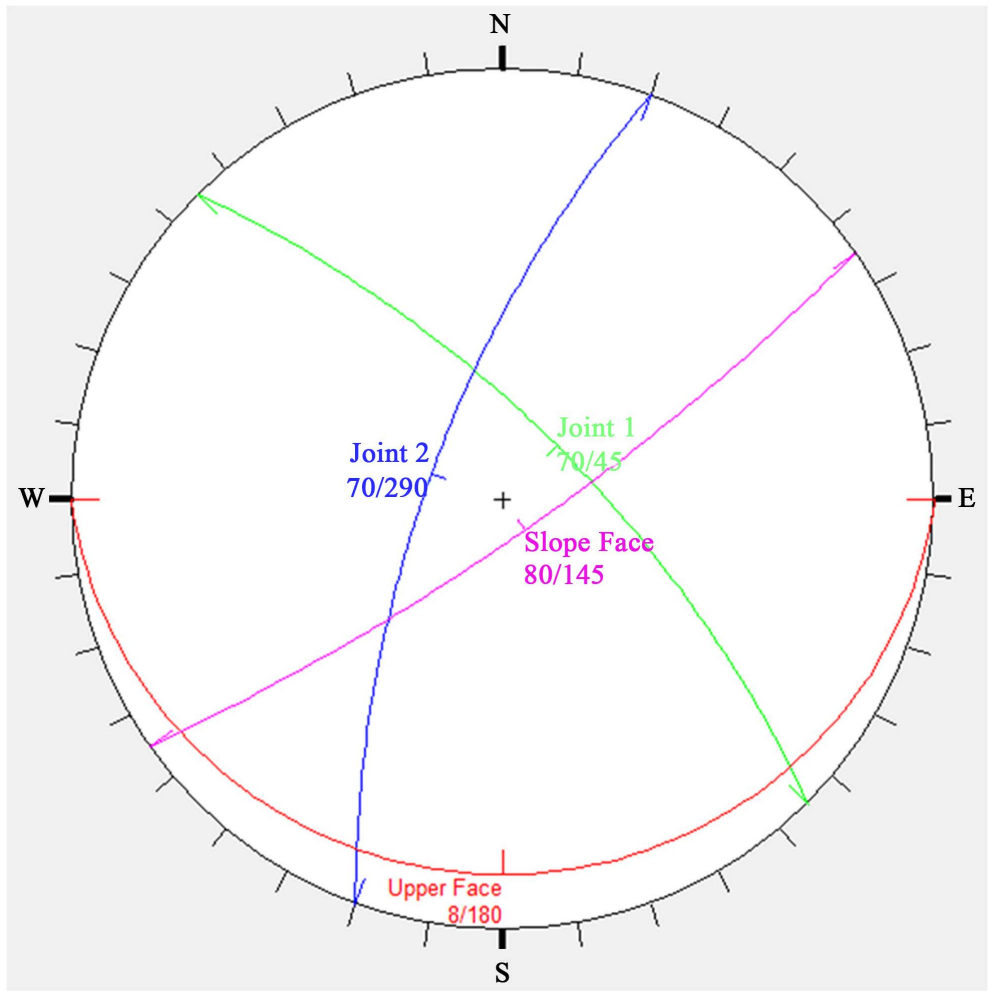

Figure 48. Stereographic images of the joint sets. 


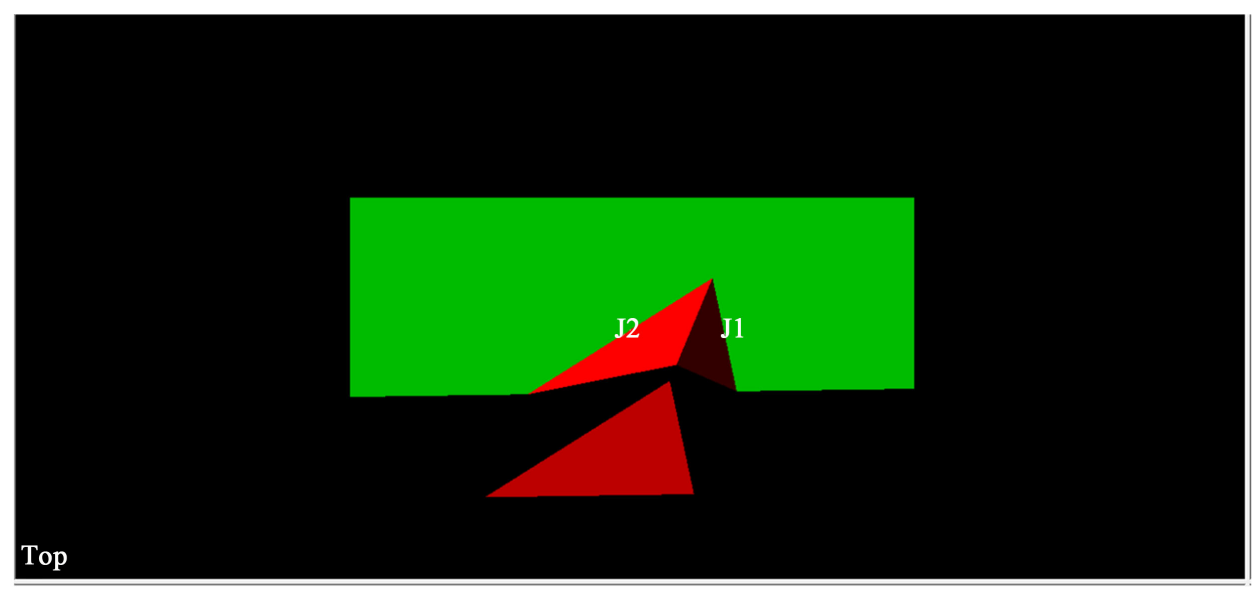

Figure 49. Top view of wedge slide analysis.



Figure 50. Front view of wedge slide analysis.

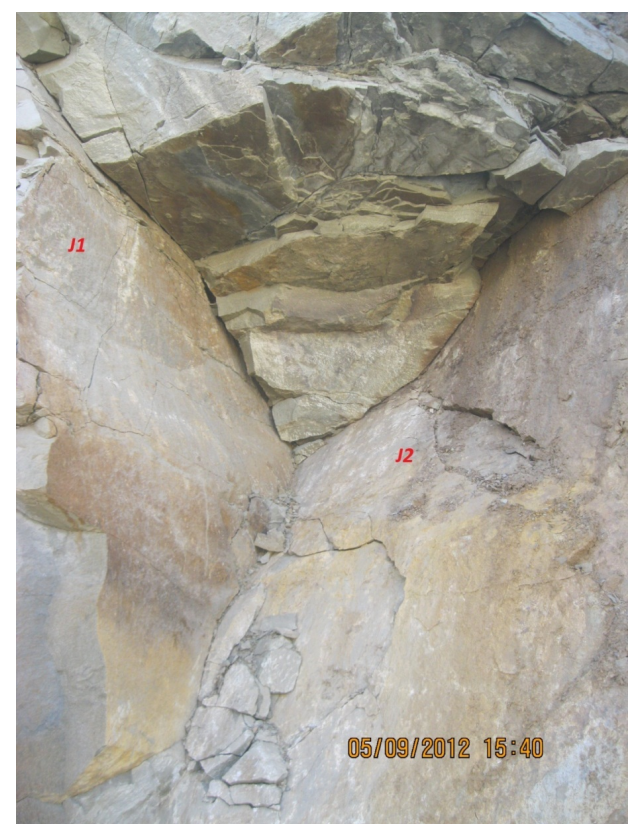

Figure 51. Front view of wedge slide. 


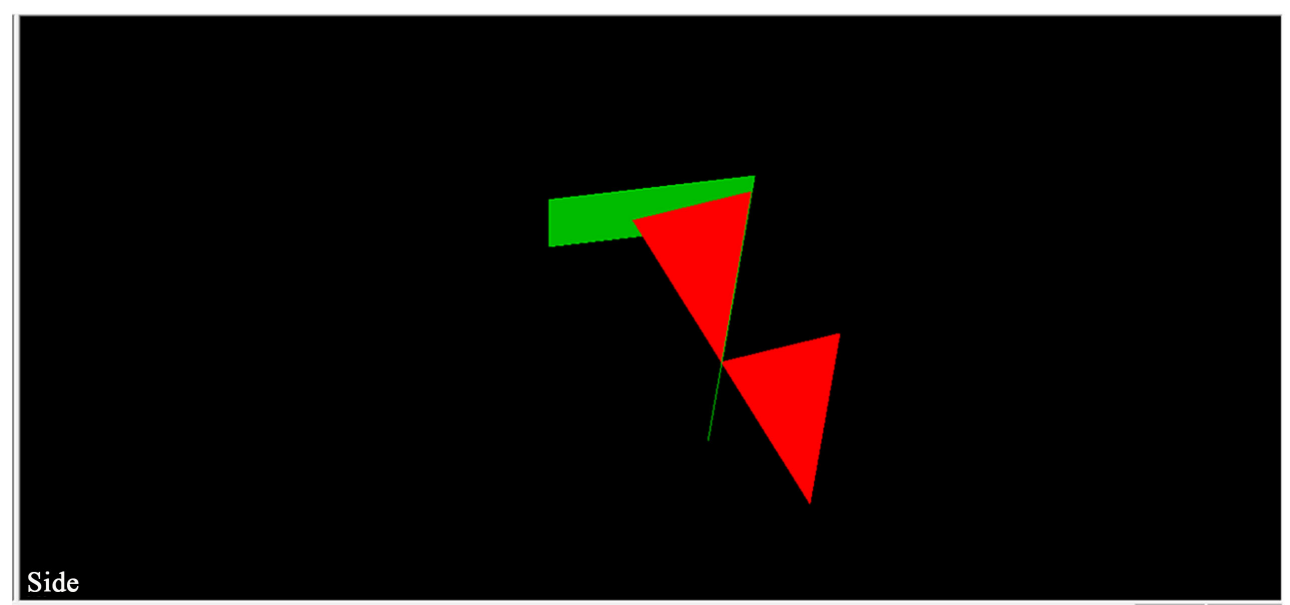

Figure 52. Side view of wedge slide analysis.

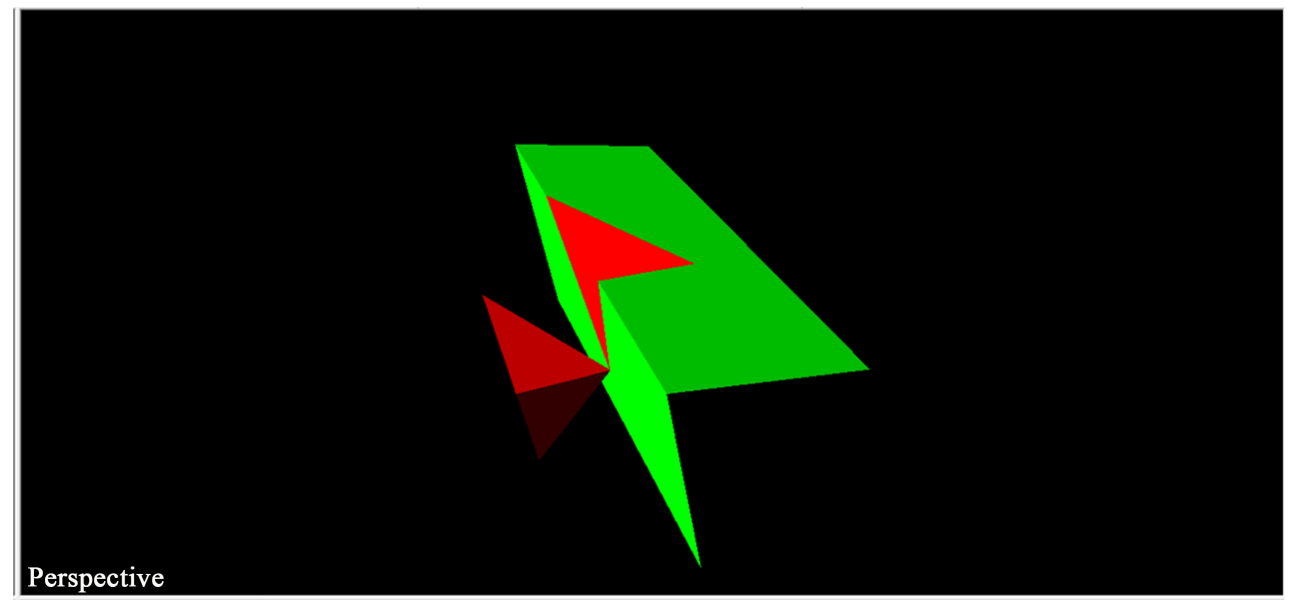

Figure 53. Perspective view of wedge slide analysis.

Table 10. Geomechanical parameters of the rock masses in unit two of the Atamir Formation K (at) 2.

\begin{tabular}{|c|c|c|c|c|}
\hline \multicolumn{2}{|c|}{ Parameter } & Min & Max & Ave \\
\hline \multicolumn{2}{|c|}{ GSI } & 40 & 50 & 45 \\
\hline \multicolumn{2}{|c|}{ Intact uniaxial compressive strength (Mpa) } & 50 & 100 & 75 \\
\hline \multicolumn{2}{|c|}{ Mi } & 11 & 23 & 17 \\
\hline \multirow{3}{*}{ Material constants } & $\mathrm{m}_{\mathrm{b}}$ & 0.154 & 1.754 & 0.828 \\
\hline & $\mathrm{S}$ & 0.0001 & 0.0014 & 0.0003 \\
\hline & A & 0.478 & 0.612 & 0.508 \\
\hline \multicolumn{2}{|c|}{ Cohesion (Mpa) } & 0.210 & 0.501 & 0.442 \\
\hline \multicolumn{2}{|c|}{ Friction angle (deg) } & 62.87 & 90.63 & 47.85 \\
\hline \multirow{4}{*}{ Rock mass parameter $(\mathrm{M}$} & Tensile strength & -0.019 & -0.08 & -0.031 \\
\hline & Uniaxial compressive strength & 0.096 & 2.68 & 1.307 \\
\hline & Global strength & 6.98 & 10.67 & 8.816 \\
\hline & Modulus of deformation & 600.75 & 1000.5 & 854.68 \\
\hline
\end{tabular}


Table 11. Characteristics of the discontinuities in unit three of the Atamir Formation K (at) 3.

\begin{tabular}{ccccc}
\hline Discontinuity & ID & Dip & Dip direction \\
\hline Js1 & 1 & 70 & 45 \\
Js2 & 2 & 70 & 290 \\
Js3 & 3 & 80 & 145 \\
bedding & 4 & 8 & 180 &
\end{tabular}

Table 12. Geotechnical characteristics of various discontinuities in rock masses of unit three in the Atamir Formation K (at) 3.

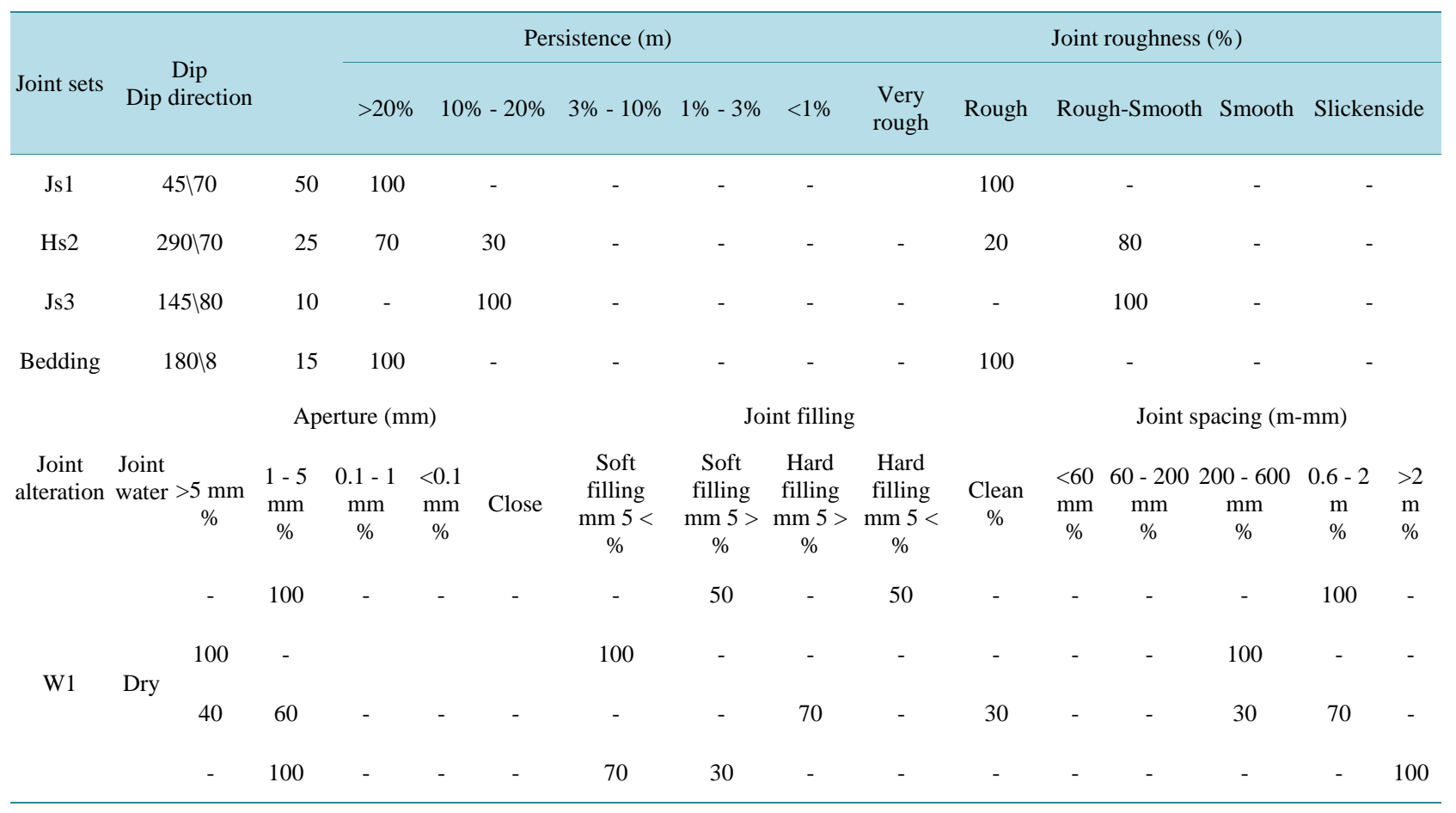

Table 13. Geomechanical classification of rock masses in unit three of the Atamir Formation K (at) 2.

\begin{tabular}{|c|c|c|}
\hline Parameter & Value & Rating \\
\hline UCS (Mpa) & $40-60$ & $4-6$ \\
\hline RQD & $25-50$ & 8 \\
\hline Spacing (mm) & $>60-200$ & 8 \\
\hline Condition of discontinuities & & 10 \\
\hline Groundwater & Dam & 7 \\
\hline RMR & \multicolumn{2}{|c|}{$35-39$} \\
\hline Class No. & \multicolumn{2}{|c|}{ Dam } \\
\hline Friction angle of the rock mass (Deg) & \multicolumn{2}{|c|}{$15-25$} \\
\hline
\end{tabular}


Table 14. The Q index of rock masses in unit three of the Atamir Formation K (at) 3.

\begin{tabular}{ccc}
\hline Parameter & Description & Value \\
\hline RQD & $37-43$ & $37-43$ \\
$\mathrm{~J}_{\mathrm{n}}$ & Three joint sets with random to four joint sets & 12 \\
$\mathrm{~J}_{\mathrm{r}}$ & Smooth to planar & 1 \\
$\mathrm{~J}_{\mathrm{a}}$ & Softening or low friction clay mineral coatings & 4 \\
$\mathrm{~J}_{\mathrm{w}}$ & Dry to medium inflow or pressure & $1-0.66$ \\
$\mathrm{SRF}$ & Medium stress, favorable stress condition & 1 \\
$\mathrm{Q}$ & & $0.51-0.89$ \\
Class No. & & Very poor rock \\
\hline
\end{tabular}

Table 15. Geomechanical parameters of the rock masses in unit three of the Atamir formation K (at) 3.

\begin{tabular}{|c|c|c|c|c|}
\hline \multicolumn{2}{|r|}{ Parameter } & Min & Max & Ave \\
\hline \multicolumn{2}{|r|}{ GSI } & 30 & 40 & 35 \\
\hline \multicolumn{2}{|c|}{ Intact uniaxial compressive strength (MPa) } & 30 & 80 & 55 \\
\hline \multicolumn{2}{|r|}{$\mathrm{Mi}$} & 9 & 17 & 13 \\
\hline \multirow{3}{*}{ Material constants } & $\mathrm{m}_{\mathrm{b}}$ & 0.457 & 0.754 & 0.366 \\
\hline & $\mathrm{S}$ & 0.0001 & 0.0009 & 0.0001 \\
\hline & A & 0.489 & 0.654 & 0.516 \\
\hline \multicolumn{2}{|r|}{ Cohesion (Mpa) } & 0.190 & 0.451 & 0.270 \\
\hline \multicolumn{2}{|r|}{ Friction angle (Deg) } & 19.05 & 50.63 & 38.41 \\
\hline \multirow{4}{*}{$\begin{array}{c}\text { Rock mass } \\
\text { parameter } \\
(\mathrm{MPa})\end{array}$} & Tensile strength & -0.021 & -0.09 & -0.012 \\
\hline & Uniaxial compressive strength & 0.023 & 1.98 & 0.426 \\
\hline & Global strength & 1.65 & 9.76 & 4.075 \\
\hline & Modulus of deformation & 600.75 & 1000.5 & 347.07 \\
\hline
\end{tabular}

Table 16. Geomechanical parameters of the rock masses in the three units of the Atamir Formation.

\begin{tabular}{ccccc}
\hline Unit & RMR & Q & GSI & Factor of safety (FS) of the wedge \\
\hline Unit one of Atamir Formation K (at) 1 & $34-36$ Poor & $0.592-0.66$ Very poor & $35-45$ Poor & 0.037 \\
Unit two of the Atamir Formation K(at) 2 & $37-41$ Poor & $0.62-0.83$ Very poor & $40-50$ Poor & 0 \\
Unit three of the Atamir Formation K (at) 3 & $35-39$ poor & $0.51-0.89$ Very poor & $30-40$ Poor & 0 \\
\hline
\end{tabular}

Table 17. Geomechanical parameters of the rock masses in unit three of the Atamir Formation K (at) 3.

\begin{tabular}{|c|c|c|c|c|c|c|}
\hline \multirow{2}{*}{$\begin{array}{c}\text { Set } \\
\text { number }\end{array}$} & \multirow{2}{*}{$\begin{array}{c}\text { Characteristics and } \\
\text { parameters of rock mass }\end{array}$} & \multicolumn{5}{|c|}{ Rating rock masses } \\
\hline & & $81-100(\mathrm{I})$ & $61-80$ (II) & $41-60$ (III) & $21-40$ (IV) & $<20(V)$ \\
\hline 1 & Rock classification & Very good & Good & Relatively good & Poor & Very poor \\
\hline 2 & $\begin{array}{c}\text { Average time of } \\
\text { self supporting capacity }\end{array}$ & $\begin{array}{l}10 \text { years for } \\
\text { active opening } \\
\text { of } 15 \text { meters }\end{array}$ & $\begin{array}{l}6 \text { months for } \\
\text { active opening } \\
\text { of } 8 \text { meters }\end{array}$ & $\begin{array}{l}1 \text { week for } \\
\text { active opening } \\
\text { of } 5 \text { meters }\end{array}$ & $\begin{array}{l}10 \text { hours for } \\
\text { active opening } \\
\text { of } 2.5 \text { meters }\end{array}$ & $\begin{array}{l}30 \text { minutes for } \\
\text { active opening } \\
\text { of } 1 \text { meter }\end{array}$ \\
\hline 3 & Cohesion of rock mass (Mpa) & $>0.4$ & $0.3-0.4$ & $0.2-0.3$ & $0.1-0.2$ & $<0.1$ \\
\hline 4 & Angle of internal friction & >45 degrees & 35 - 45 degrees & 25 - 35 degrees & 15 - 25 degrees & $<15$ degrees \\
\hline 5 & Load bearing capacity $\left(\mathrm{T} / \mathrm{M}^{2}\right)$ & $440-600$ & $280-440$ & $135-280$ & $45-135$ & $30-45$ \\
\hline
\end{tabular}


Therefore, rockslide has been unavoidable in rock masses of all three units. The point of great importance is the mass movement of the rocks towards the road and channel that has blocked them and will cause floods during future rainfalls. Based on observations made, the process of landslide under discussion has not ended, and it seems that a long time has to pass (from several months to several years) for stability to be established.

Condition of the rock masses (Table 16).

Considering the RMR stability table (Table 17).

\section{References}

[1] Feenstra, R. and Wickham, J. (1975) Evolution of Folds around Broken Bow Uplift, Ouachita Mountains, Southeastern Oklahoma. AAPG Bulletin, 59, 974-985.

[2] Bieniawski, Z.T. (1973) Engineering Classification of Jointed Rock Masses. Civil Engineer in South Africa, 15, 353.

[3] Cai, M., Kaiser, P.K., Uno, H., Tasaka, Y. and Minami, M. (2004) Estimation of Rock Mass Strength and Deformation Modulus of Jointed Hard Rock Masses Using the GSI System. International Journal of Rock Mechanics and Mining Sciences, 41, 3-19. http://dx.doi.org/10.1016/S1365-1609(03)00025-X 